
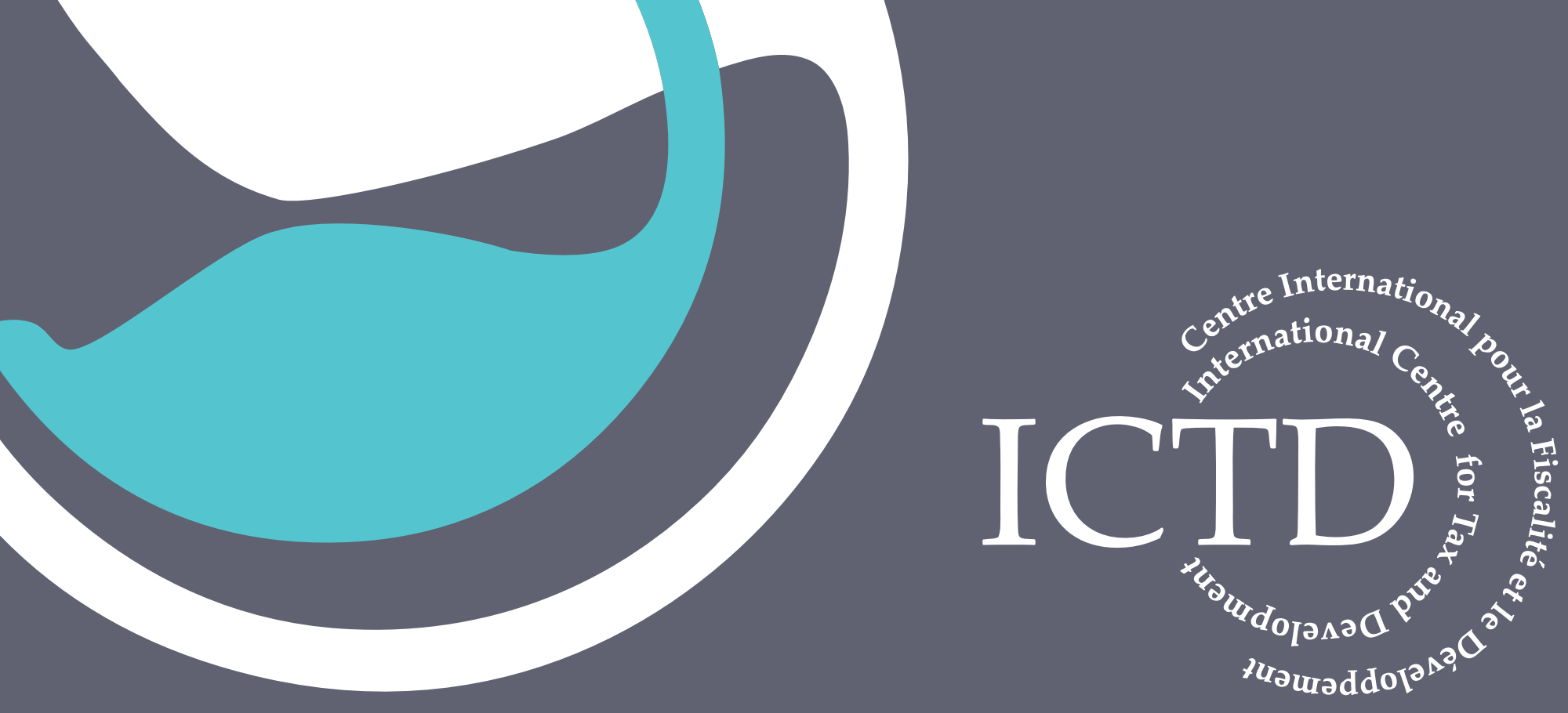

Working Paper 27

\title{
International Distribution of the Corporate Tax Base: Implications of Different Apportionment Factors under Unitary Taxation
}

Alex Cobham and Simon Loretz

November 2014 
ICTD Working Paper 27

International Distribution of the Corporate Tax Base: Implications of Different Apportionment Factors under Unitary Taxation

Alex Cobham and Simon Loretz

November 2014 
International Distribution of the Corporate Tax Base: Implications of Different Apportionment Factors under Unitary Taxation Alex Cobham and Simon Loretz

ICTD Working Paper 27

First published by the Institute of Development Studies in November 2014

(C) Alex Cobham and Simon Loretz 2014

ISBN: 978-1-78118-178-2

The authors of this paper grant to the IDS and the ICTD a perpetual, irrevocable, worldwide, royalty-free, non-exclusive licence, or sublicence, to reproduce, communicate to the public, use, adapt, publish, distribute, display and transmit the work in any and all media, and to sublicense others (including the Crown) to reproduce, communicate to the public, use, adapt, publish, distribute, display and transmit the work in any and all media, for non-commercial purposes and with appropriate credit being given to the authors and ICTD funders.

A catalogue record for this publication is available from the British Library.

This work has been licensed by the copyright holder for distribution in electronic format via any medium for the lifetime of the OpenDocs repository for the purpose of free access without charge and can be found at http://opendocs.ids.ac.uk/opendocs/

\section{Also available from:}

International Centre for Tax and Development,

Institute of Development Studies,

Brighton BN1 9RE, UK

Tel: +44 (0) 1273606261 Fax: +44 (0) 1273621202

E-mail: info@ictd.ac

Web: www.ictd.ac

IDS is a charitable company limited by guarantee and registered in England (No. 877338) 


\title{
International Distribution of the Corporate Tax Base: Implications of Different Apportionment Factors under Unitary Taxation
}

\author{
Alex Cobham and Simon Loretz
}

\section{Summary}

Under the current system of separate accounting, tax-motivated international profit shifting results in misalignment of profits and real economic activity. While the Organisation for Economic Co-operation and Development (OECD) Base Erosion and Profit Shifting initiative aims to measure and curtail this, critics claim serious progress is only possible with greater emphasis on formulary apportionment methods (Picciotto 2013), or other methods outside the present international tax architecture (IMF 2014). In this paper we use the leading global database of company balance sheets to compare the distribution of profit and potential apportionment factors. Although data coverage is problematic for developing countries, we find that apportioning profit according to measures of actual economic activity would result in a major redistribution of the tax base at the expense of a particular group of jurisdictions, and in most cases towards the lower-income countries in the sample. International loss consolidation facilitated by a global switch to unitary taxation would reduce the overall tax base by around 12 per cent.

Keywords: corporate tax reform; multinational taxation; formula apportionment; unitary taxation; base erosion; profit shifting; BEPS.

Alex Cobham is a Research Fellow at the Center for Global Development.

Simon Loretz is head of the public finance group at the Institute for Advanced Studies, Vienna. 


\section{Contents}

Summary 3

Acknowledgements $\quad 5$

Acronyms 5

Introduction $\quad 6$

$1 \quad$ Previous literature $\quad 9$

2 Mechanisms of formulary apportionment and loss consolidation $\quad 10$

2.1 Basic measure of formulary apportionment 10

$\begin{array}{lll}2.2 & \text { The role of (international) loss consolidation } & 12\end{array}$

3 Data and empirical approach 13

3.1 Data 13

$\begin{array}{ll}3.2 & 16\end{array}$

$4 \quad$ Empirical results 17

4.1 Tax base effects 17

4.2 Tax revenue effects $\quad 25$

$\begin{array}{lll}4.3 & \text { Results using segmental reporting } & 28\end{array}$

5 Conclusion $\quad 29$

$\begin{array}{ll}\text { Appendix } & \mathbf{3 0}\end{array}$

$\begin{array}{ll}\text { References } & 36\end{array}$

Tables

Table 1 Number of firms in MNE groups, by location and owner country groups 15

Table 2 Descriptive statistics profit and loss and apportionment factors 16

Table 3 Baseline results for total assets as apportionment factor 19

Table 4 Baseline results for different apportionment factors 23

Table 5 Results for tax reported, balanced subsample for different $\begin{array}{ll}\text { apportionment factors } & 27\end{array}$

Table 6 Results for profit allocation using segmental reporting 28

Table A1 Baseline results for tangible assets as apportionment factor 30

Table A2 Baseline results for turnover as apportionment factor 31

Table A3 Baseline results for number of employees as apportionment factor 32

Table A4 Baseline results for payroll as apportionment factor 33

Table A5 Baseline results for two-part apportionment factor according to
Avi-Yonah et al. (2009) - 1 per cent return in the first stage

Table A6 Baseline results for two-part apportionment factor according to

Avi-Yonah et al. (2009) - 5 per cent return in the first stage 35

Figures

Figure 1 Tax base allocation over time: apportionment by total assets 21

Figure 2 Tax base apportionment: variation across factors 24

Figure 3 Tax base apportionment: variation across countries 25 


\section{Acknowledgements}

We acknowledge useful discussions with Sol Picciotto, Carolin Holzmann and workshop participants at the International Centre for Tax and Development (ICTD), the 70th conference of the International Institute of Public Finance, and seminar participants at the Center for Global Development. We are grateful for support for this work from ICTD, which has received funding from the Department for International Development (DFID) and the Norwegian Agency for Development Cooperation (NORAD). We thank Hendrik Jungmann for excellent research assistance.

\section{Acronyms}

$\begin{array}{ll}\text { BEPS } & \text { Base Erosion and Profit Shifting } \\ \text { CCCTB } & \text { Common Consolidated Corporate Tax Base } \\ \text { EU } & \text { European Union } \\ \text { FDI } & \text { Foreign Direct Investment } \\ \text { ICTD } & \text { International Centre for Tax and Development } \\ \text { IMF } & \text { International Monetary Fund } \\ \text { OECD } & \text { Organisation for Economic Co-operation and Development } \\ \text { US } & \text { United States }\end{array}$




\section{Introduction}

The growing importance of multinational corporations and their opportunity to reduce their tax bill via international reallocation of the corporate tax base has been a topic of considerable interest both to academic researchers and to policymakers. ${ }^{1}$ In light of the fiscal pressures arising from the recent financial crisis there has been further impetus to the debate by the OECD's Base Erosion and Profit Shifting (BEPS) initiative, launched in 2013 with the backing of the G8 and G20 groups of countries.

The UK's Chancellor of the Exchequer, George Osborne, reflected the strength of criticism of the current system when he hailed the BEPS Action Plan as 'a major step forward towards a global tax system that is fair and fit for purpose'. ${ }^{2}$ The Action Plan (OECD 2013) declares that 'A realignment of taxation and relevant substance is needed' ( $p .13)$, and takes as its aim that it 'should provide countries with domestic and international instruments that will better align rights to tax with economic activity' (p.11). ${ }^{3}$

Under the current system of separate accounting, profits of multinational companies are taxed in the respective countries in which they are earned. For the purpose of corporate taxation, the subsidiaries of these companies are treated as individual firms when it comes to calculation of the taxable profits. ${ }^{4}$ Given the persistent disparities in corporate tax rates, this creates an incentive for multinational companies to misallocate their taxable income with the aim of reducing their overall tax burden. There are a number of empirical studies using corporate balance sheet data which support the hypothesis that international profit shifting in response to tax differentials is statistically and economically significant within European Union (EU) and OECD countries. ${ }^{5}$

Similar evidence for developing countries is lacking, reflecting the scarcity of balance sheet data. Instead researchers in this area have tended to focus on analysis of trade data, where abnormal pricing suggests large illicit outflows from developing countries, but where attribution to multinational tax practices is problematic - see, for example, the range of views among contributors to the World Bank's major volume on illicit financial flows (Reuter 2012, including Eden 2012; Fuest and Riedel 2012; Leite 2012; Murphy 2012; and Nitsch 2012).

In order to restrict tax-motivated relocation of corporate profits, increasingly complex approaches have emerged to transfer pricing, thin capitalisation, questions of permanent residence and related issues. The application of these rules varies widely, even between OECD member states, and a critical view is that BEPS is primarily addressing the difficulties of the system of separate accounting, rather than addressing the fundamental problem - the system itself. The International Monetary Fund (IMF), arguably the leading international institution in terms of developing country tax advice, has stated bluntly that 'Current

\footnotetext{
For a recent survey on the topic, see Fuest et al. (2013).
}

Osborne's comments were made in the UK government's press release at <https://www.gov.uk/government/news/g20next-stage-in-securing-new-global-standard-for-tackling-avoidance-and-evasion-reached> (accessed 10 March 2014).

3 It is interesting that the OECD has set this target for the BEPS initiative, since alignment of profit and economic activity is not the aim of the current system. Under the separate accounting approach misalignments will reflect not only tax motivated 'profit shifting', but also differences in the actual profitability of different entities within a particular multinational group. There is also no articulated theoretical basis for alignment as a goal of international tax rules - a potentially important avenue for future research.

$4 \quad$ For a detailed description on the historical origins and the resulting shortcomings of the current international tax system see Picciotto (2013)

See Grubert and Mutti (1991) for early evidence for the US; Huizinga and Laeven (2008), Weichenrieder (2009) and Loretz and Mokkas (2011) for more recent evidence for European multinationals. 
initiatives, which operate within the present international tax architecture, will not eliminate spillovers' (IMF 2014: 35). ${ }^{6}$

The alternative of unitary taxation has been proposed: treating each multinational group of companies as a unit, regardless of the geographical and juridical location of the individual subsidiaries; calculating profit and loss on a group-wide basis; and then allocating the taxing rights on this consolidated profit between the jurisdictions with which the group has a nexus, according to the extent of actual economic activity. Systems of unitary taxation with formula apportionment currently exist only at the national level, most notably in the United States (US), Canada and Switzerland, and - for local business tax - in Germany. There is also a longstanding proposal of the European Commission (2011) to extend unitary taxation and formulary apportionment to the whole of the European Union under the Common Consolidated Corporate Tax Base (CCCTB).

In practice, OECD transfer pricing guidelines allow a range of methods to allocate (or apportion) profit between entities within a group, so rather than seeing a choice between polar opposite systems it is possible to think of changes within the current framework that would make the extent of apportionment more coherent and transparent (Picciotto 2013). As such, research into the distributive implications of full global apportionment also shed light on the direction of travel that would follow from more gradual steps.

The underlying idea of the allocation formulae (which may typically include assets, sales and employment) is that they should reflect economic substance: that is, they should reflect the location of corporate economic activity across countries. As such, any assessment of tax base redistribution under a particular formula will to some extent reflect the misalignment between current profit declaration and the location of economic activity, as captured by the formula in question. The disparity between the allocation of the apportionment factors and the taxable profit is likely also to reflect differences in productivity or in the valuation of the apportionment factor in question, and therefore might have non-tax reasons. Therefore any strong conclusions about tax-induced misalignment should be drawn with utmost care.

Sales factors reflect the demand for goods and services, while labour and assets reflect the supply process. There is no 'true' formula that objectively captures the location of economic activity, but a number of formulae are in operation or have been proposed, and this paper considers a range of these. The specific apportionment formula chosen is likely to have substantial redistributive consequences - given that proposals for unitary taxation originate largely from the observation that profits are misaligned under the current system, redistribution of taxable income is the logical consequence.

The most active proponents of international formulary apportionment have been EU countries, suggesting they are expecting to benefit in the form of more tax base allocated to them. At the same time, critics of the current system have long highlighted that reliance on transfer pricing and the arm's length principle may produce a systematic distortion of the tax base away from developing countries. ${ }^{7}$ While both OECD countries and developing countries could plausibly gain tax base at the expense of low tax jurisdictions with disproportionate profit declaration, the identity of the winners and losers will depend on the nature of the current distribution of declared profits and on the precise formula used. While there has been some analysis of revenue effects of different formulae for the US and the European Union, it has not yet been investigated at a worldwide level.

Rather than emphasise profit misalignment, the IMF uses the broader concept of spillovers in international corporate taxation (defined as the effect of one country's rules and practices on others). IMF (2014: 1) highlights that adverse spillovers are 'especially marked and important for developing countries'.

See, for example, Cobham and McNair (2012). 
This paper aims to investigate the revenue consequences of various apportionment factors, with the particular intention of extending knowledge of the distributional implications beyond the major industrialised countries. There are reasons to think that the current system of separate accounting and transfer pricing may raise particular difficulties for developing countries (OECD 2014). The pattern of investment may also differ, with lower-income countries receiving a greater share of vertical investment focused on resource extraction and use of low cost labour, compared to horizontal investment, primarily for market access reasons. Differences in factor prices in lower-income countries are also likely to have a direct impact on the revenue consequences of the choice of apportionment factor. At the same time it is crucial to point out that we fully abstract from behavioural changes of multinational companies in response to the move towards unitary taxation with formula apportionment. Insofar as we believe that part of the redistribution of the corporate tax base is due to profit shifting activities under the current system, it is very likely that companies will adjust their behaviour and that allocation of real assets will be affected by corporate taxation. This is a very important aspect of a change towards unitary taxation which is beyond the scope of this paper, but certainly needs to be the focus of future research.

Finally, data availability presents a particular challenge in assessing tax changes in lowerincome countries. Hence this study aims to both explore what we can learn from available data, and highlight where data shortcomings are particularly pronounced. In this way the current study fits with Action 11 of the BEPS initiative, aiming to 'establish methodologies to collect and analyse data on BEPS and the actions to address it'. Data availability in respect of lower-income countries is likely to be a major problem for the OECD when ensuring that their baseline data and subsequent monitoring has global coverage.

We use the largest commercially-available database of company balance sheets, Orbis, provided by Bureau van Dijk. Using a dataset of up to 211,360 individual companies in 26,795 corporate groups, we simulate the static distributional consequences of a number of different apportionment factors. The most obvious finding is that coverage is severely limited among developing countries, and increasingly so for lower-income countries. Despite the large number of firms in the initial dataset, the level of reporting for lower-income countries is insufficient to predict revenue consequences reliably. The challenge for the OECD BEPS initiative is clear.

Nevertheless, our study highlights some interesting aspects of a move towards unitary taxation and formula apportionment. A first robust finding is that the implicit introduction of international loss consolidation would reduce the overall corporate tax base significantly - in our sample of firms for the years $2003-2011$ by more than 10 per cent. Furthermore, the exact design of the apportionment mechanism will be crucial for the distribution of the corporate tax base between countries. While this result is neither surprising nor new, it highlights the likely political difficulties that would arise in seeking multilateral agreement on a specific formula.

The analysis in this paper is based on all the countries in the world participating in the move to unitary taxation with formula apportionment. In reality it is much more likely that tax havens and other countries benefitting from the current separate accounting system will opt to stay out of a unitary taxation system. We do not model this in the current paper, but previous results have shown that if only high tax countries move to a formula apportionment system, in relation to profits arising within their own economies, the revenue consequences will be much less pronounced. ${ }^{8}$ Alternatively, a country or economic region (e.g. the EU or the East African Community) might unilaterally decide to apply unitary taxation in order to determine their apportioned share of the worldwide profits of multinational groups operating in their 
jurisdiction. The results here shed light on the potential scale of change in the tax base before the effect of any subsequent decisions about tax rates and the location of economic activity.

Despite the shortcomings of the data, a remarkably clear picture emerges. Of the countries with sufficient data, those with lower per capita income would benefit from apportionment according to either tangible assets or number of employees. In contrast, apportionment according to turnover or cost of employees will allocate a larger share to higher income countries. Similarly a two-part apportionment formula in the spirit of Avi-Yonah et al. (2009) would also benefit high-income high-tax countries (here the assumed rate of return on operating expenses crucially affects the results). Finally we investigate the impact on tax revenue, which seems to be slightly positive (in the range of two to four per cent) - although strong assumptions are necessary to make such an estimate.

The paper is structured as follows. Section 1 discusses the literature on unitary taxation and formulary apportionment. Section 2 outlines algebraically the approach taken to apportionment, including the role of international loss consolidation. Section 3 presents the data and outlines the empirical approach, with the results being set out in Section 4. A final section concludes.

\section{Previous literature}

Given the gap in research addressing the empirical implications of a shift to unitary taxation for lower-income countries, this paper is most closely related to two different research questions. One strand of literature is mostly concerned with profit shifting out of the US, and investigates how much more tax base would be allocated to the US if they were to extend unitary taxation and formula apportionment to the worldwide income of US-headquartered multinationals. Shackelford and Slemrod (1998) use segmental reporting data, and show that 46 of the largest US firms would face a 38 per cent increase in their tax burden. Clausing and Lahav (2011) update the analysis of Shackelford and Slemrod, but find only a modest increase of the tax base in the US. While this approach is appealing because it uses consolidated group profits as a starting point, it is highly data-demanding and therefore was only conducted for a small number of companies. Furthermore, segmental reporting does not usually allow identification of the distribution of the apportionment factors in all countries, and hence the two studies are limited to the revenue impacts on the headquarters economy.

A range of studies have considered the application of formulary apportionment within national borders. Mintz and Smart (2004) find that apportionment between Canadian provinces results in substantially less income shifting. Where Canada has a common formula (based on sales and wages), US states can apply their own factors. Clausing (2014: 25) assesses the experience in the US, and finds 'some cautious optimism for advocates of international formulary apportionment. Formulary apportionment has the potential to reduce income-shifting incentives without generating accompanying large tax responses in economic activity such as employment and investment'.

A different approach is used in papers addressing the revenue impact of various potential apportionment factors in the context of European tax harmonisation. Here the approach is bottom-up, as the information of the subsidiaries is aggregated to obtain the geographical distribution of the profits and the apportionment factors. Fuest et al. (2007) use data about German inbound and outbound foreign direct investment (FDI), while Devereux and Loretz (2008) use international data to investigate the same questions. Aside from the higher quality of the German administrative data used by Fuest et al. (2007) and the broader coverage in the international data used by Devereux and Loretz (2008), the main difference in approach 
is that the latter explicitly model the impact of international loss consolidation. Devereux and Loretz (2008) also investigate the impact of a voluntary system of formula apportionment, since this is discussed in the European Union.

The core of the current paper is an extension of Devereux and Loretz (2008) to all countries for which equivalent balance sheet data is available. In addition to the apportionment factors proposed by Agúndez-García (2006), we also consider the two-part apportionment discussed in Avi-Yonah et al. (2009). This method allocates ordinary profits according to the geographical distribution of operating expenses, and excess profits are then allocated according to additional factors (e.g. assets). Very recently IMF (2014) uses Bureau of Economic Analysis investment data on US outbound FDI to investigate the impact of different apportionment factors on tax revenue in selected advanced and emerging countries. This provides a sample with broad international coverage in terms of host economies, but narrow by home economy (i.e. US only). In addition, data is from survey responses rather than audited accounts. Nonetheless there are important commonalities in the findings, which we discuss briefly in Section 4.

\section{Mechanisms of formula apportionment and loss consolidation}

The main question we are concerned with in this paper is which countries could benefit from a move to unitary taxation through a larger corporate tax base being apportioned to them (once international loss consolidation is allowed for). Note that apportionment of a larger tax base need not necessarily imply higher ultimate revenue, since the change in system would change both states' incentives for setting rates, and corporate incentives for the location of economic activity. Nonetheless, relative changes in tax base are significant to the extent that they reflect the relative power of states in terms of any subsequent revenue-investment trade-off.

To answer this question this section first sets out to describe the basic mechanism of formula apportionment, and how we can compare the tax base under separate accounting to the hypothetically-apportioned tax base under unitary taxation with different formulae. Then we highlight the role of international loss consolidation under unitary taxation.

\subsection{Basic mechanism of formula apportionment}

Let $\pi_{i f}$ denote the declared, taxable profit of corporate group $j$ in country $i$. The total declared taxable profit of the group across all $N_{j}$ countries in which it operates, is then given by $\Pi_{j}=\sum_{i=1}^{N_{j}} \pi_{i j}$.

Under the current system of separate accounting the corporate group is liable to corporate taxation on its profit in each country $\pi_{i j}$ at the corporate tax rate $\tau_{i}{ }^{9}$ For the moment, let us assume that the group is profitable in all countries where it operates. Hence under separate accounting the total tax revenue of each country is $i$ given by:

Note that for reasons of simplicity we do not distinguish between one or many subsidiaries of the same corporate group in a given country. In countries where (loss) consolidation between members of a group is not possible, this distinction might be important. 


$$
T_{i}^{S A}=\sum_{j=1}^{J_{i}} \tau_{i} \pi_{i j}
$$

where $J_{i}$ denotes the number of groups country $i$.

In contrast, under a unitary taxation approach the taxable profit of the corporate group is aggregated first, and then taxing rights are allocated to the individual countries according to a formula. Abstracting from the possibility that countries chose their own formula this yields total tax revenue for each country of:

$T_{i}^{U T}=\sum_{j=1}^{J_{i}} \tau_{i} \theta_{i j X} \Pi_{j}$

where $\theta_{i j X}$ is the share of the total profit allocated to country $i$ if factor $X$ is used to apportion the profits among the $N_{j}$ countries in which group $j$ operates, and is defined according to:

$0 \leq \theta_{i j X} \equiv \frac{X_{i j}}{\sum_{i=1}^{N_{j}} X_{i j}} \leq 1$

Note that the share of the apportionment factor is bounded between zero and unity under normal circumstances (i.e. the apportionment factor is non-negative in all countries). In the case of the two-part apportionment process proposed by Avi-Yonah et al. (2009) the apportionment factor will be

$0 \leq \theta_{i j X} \equiv \frac{p E_{i j}}{\Pi_{j}}+\left(1-\frac{p \sum_{i=1}^{N_{j}} E_{i j}}{\Pi_{j}}\right) \frac{X_{i j}}{\sum_{i=1}^{N_{j}} X_{i j}} \leq 1$

where $E_{i j}$ denotes the operating expenses of group $j$ in country $i$, and $p$ the assumed standard return to the expenses.

In consequence country $i$ will receive higher tax revenue from group $j$ under unitary taxation if the following condition is fulfilled:

$T_{i j}^{U T}>T_{i j}^{S A} \Leftrightarrow \frac{X_{i j}}{\sum_{i=1}^{N_{j}} X_{i j}}>\frac{\pi_{i j}}{\sum_{i=1}^{N_{j}} \pi_{i j}} \Leftrightarrow \theta_{i j X}>\frac{\pi_{i j}}{\prod_{j}}$

The condition in (5) simply states that a country will receive more tax revenue from a multinational group if the share of the apportionment factor in the country is bigger than the share of profits reported in the country under separate accounting.

To generalise, this will hold for the overall corporate tax revenue of the country by using the average over all multinational groups with a taxable nexus in the country. ${ }^{10}$ That is, if the average share of the apportionment factor $\left(\overline{\theta_{i j X}}\right)$ across all groups is larger than the average share of profit, tax revenue will be higher under unitary taxation. Denoting the average worldwide profit of multinationals with a nexus in the country as $\bar{\Pi}_{j}$, and the average profit in this country of these multinationals $\overline{\pi_{i j}}$, we have:

$10 \quad$ Note that the last steps in equations (6) and (9) only work if the number of groups with a taxable nexus does not change through the switch from separate accounting to unitary taxation. For example, in the case of apportionment by sales by destination this could imply the use of throwback rules. 
$T_{i}^{U T}>T_{i}^{S A} \Leftrightarrow \sum_{j=1}^{J_{i}} T_{i j}^{U T}>\sum_{j=1}^{J_{i}} T_{i j}^{S A} \Leftrightarrow \frac{\sum_{j=1}^{J_{i}} X_{i j}}{\sum_{j=1}^{J_{i}} \sum_{j=1}^{N_{j}} X_{i j}}>\frac{\sum_{j=1}^{J_{i}} \pi_{i j}}{\sum_{j=1}^{J_{i}} \Pi_{j}} \Leftrightarrow \overline{\theta_{i j X}}>\frac{\overline{\pi_{i j}}}{\overline{\Pi_{j}}}$

In other words, a country will receive more tax revenue from multinational groups if the average share of the apportionment factor for all groups in the country is bigger than the average share of profits reported in the country under separate accounting.

Finally, note that for any given formula which is considered to reflect actual economic activity (e.g. an equally-weighted combination of sales, employment and fixed assets), the ratio of tax revenue - or equally, of tax bases, since the $\tau_{i}$ will drop out - under unitary and separate accounting will provide a measure of the misalignment between profit and activity.

\subsection{The role of (international) loss consolidation}

An additional aspect to be considered is the consolidation of losses within the corporate group. In most countries corporations do not get immediate relief for losses, but rather can use the losses against profits in other subsidiaries in the same country, or carry them forward to be offset against future profits. However, with very few exceptions losses cannot be offset against profits made in subsidiaries in other countries. ${ }^{11}$

This situation changes when group-wide profit is calculated under unitary taxation. The resulting elimination of differences in the treatment of domestic and foreign losses is a major argument used by the EU in support of a move to CCCTB. These considerations have an important effect on tax revenue both under the current system and proposals for unitary taxation. Under the current system the taxable income and tax liabilities of an individual firm $j$ in country $i$ need to be adjusted to reflect the loss carry forward and the asymmetric treatment of profit and losses. Let $t$ denote the taxable year and $\lambda_{i j, t-1}$ the losses brought forward into the period, one can rewrite the taxable income and the loss carry forward of current period as

$\pi_{i j, t}^{S A}=\max \left(0,\left(\pi_{i j, t}+\lambda_{i j, t-1}^{S A}\right)\right)$ and $\lambda_{i j, t}^{S A}=\min \left(0,\left(\pi_{i j, t}+\lambda_{i j, t-1}^{S A}\right)\right)$,

which can then be aggregated to the total taxable profit under separate accounting $\Pi_{j, t}^{S A}=\sum_{i=1}^{N_{j, t}} \pi_{i j, t}^{S A}$.

Under a unitary taxation approach, losses in individual countries will be immediately offset against the profits elsewhere, and losses will only be carried forward at the corporate group level. Hence the profit and the loss carry forward will be

$$
\Pi_{j, t}^{U T}=\max \left(0,\left(\Pi_{j, t}^{U T}+\Lambda_{j, t-1}^{U T}\right)\right) \text { and } \Lambda_{i j, t}^{U T}=\min \left(0,\left(\Pi_{j, t-1}^{U T}+\Lambda_{j, t-1}^{U T}\right)\right)
$$

Hence with the current asymmetric loss treatment, the total corporate tax base will be different depending on the tax system. Changing from a system of separate accounting to unitary taxation may have a short-run transition effect because of stocks of losses in the 
respective countries. ${ }^{12}$ However, even abstracting from this short-run transition effect, the switch from separate accounting to unitary taxation has two counteracting effects on the overall tax base. First, there is the direct effect that more losses are usable immediately, which has a depressing effect on the overall tax base. At the same time, the fact that losses are more likely to be used immediately implies that the stock of losses to be carried forward will be smaller. This has a positive impact on the overall tax base. Which of the two effects dominates depends on the level and the variance of the expected profits.

Taking into account that the overall tax base will be different under the two tax systems, the condition under which any individual country will be better off can now be written as.

$T_{i, t}^{U T}>T_{i, t}^{S A} \Leftrightarrow \sum_{j=1}^{J_{i, t}} T_{i j, t}^{U T}>\sum_{j=1}^{J_{i, t}} T_{i j, t}^{S A} \Leftrightarrow \frac{\sum_{j=1}^{J_{i, t}} X_{i j, t}}{\sum_{j=1}^{J_{i, t}} \sum_{i=1}^{N_{j, t}} X_{i j, t}}>\frac{\sum_{j=1}^{J_{i, t}} \pi_{i j, t}^{S A}}{\sum_{j=1}^{J_{i, t}} \Pi_{j, t}^{U T}} \Leftrightarrow \overline{\theta_{i j X, t}}>\frac{\overline{\pi_{i j, t}^{S A}}}{\overline{\Pi_{j, t}^{U T}}}$

A country will receive relatively more tax base under unitary taxation if the average share of the apportionment factor is bigger than the average ratio between the profit under separate accounting to the total taxable profit under unitary taxation.

A final complication arises when the two-part apportionment proposed by Avi-Yonah et al. (2009) is used. If the overall profit of the corporate group is positive but smaller than the assumed return on expenses, the residual profit to be apportioned in the second stage is negative which can result in an overall negative tax base allocated to some countries. In this case we set the apportionment factor in this country to zero. Technically this implies that the inequality in equation (4) does not necessarily hold, since it is possible that the assumed return on expenses is larger than the overall profits.

\section{Data and empirical approach}

To address the questions raised here one would ideally have access to country-by-country reporting of profits and losses, as well as of the relevant apportionment factors. At present this is not available for all companies worldwide. However, international civil society campaigning has resulted in its being required for extractive sector companies listed in the EU and USA, and the OECD has been mandated by the G8 and G20 groups of countries to create a standard for private country-by-country reporting to tax authorities. ${ }^{13}$

\subsection{Data}

In the current absence of the ideal dataset, we use the largest available dataset of firm-level accounts, Orbis, provided by Bureau van Dijk. Orbis contains the balance sheet, profit and loss accounts, and most crucially the ownership structure, of all registered companies worldwide. For a subset of headquarter countries, both the consolidated and the unconsolidated accounts are available. For the main approach of this paper we follow Devereux and Loretz (2008), and aggregate the individual unconsolidated accounts to obtain the necessary country-by-country information. This results in an incomplete picture, since information is often unavailable for some of the subsidiaries within a group. In addition,

It is not clear whether one would want to include stocks of losses into the calculation of current taxable profits. There is also the proposed solution that stocks of losses may be carried forward against the tax liability resulting from the apportioned share of profits.

13 Part of the basis for the international civil society campaign has been, precisely, its potential to demonstrate the misalignment of profits and activity, and, for some, to make the case for unitary taxation. See e.g. Murphy (2008) on the country-by-country proposal and the argument for the wider public to be able to scrutinise multinational groups' tax payments. 
where there are non-random reasons for information to be missing (e.g. accounts in low-tax jurisdictions are less likely to be included in the dataset), this will result in systematic biases to the results. Notwithstanding these issues, however, our view is that at the current moment Orbis provides the best opportunity to consider patterns among multinational groups of global origin - albeit from a limited field.

In principle the Orbis online database contains all firms worldwide, and currently amounts to approximately 100 million entries. ${ }^{14}$ However, for the vast majority of these companies there is only very basic information, such as name and address. At the same time, any switch from separate accounting to unitary taxation will not directly affect small independent and purely domestic companies. Therefore the starting point of the analysis is to identify which companies will be affected by a switch to unitary taxation. Since this study focuses on the revenue effects of different apportionment factors, and is not concerned with other important aspects of a change towards unitary taxation, the companies which will be affected need to be multinational groups. We define multinational groups as corporate groups which own at least one subsidiary in a different country. We define ownership as owning either directly or indirectly more than 50 per cent, which implies that we can allocate any subsidiary unambiguously to its owner. Further we exclude public authorities or individuals owning corporate groups. In cases where a multinational group is globally owned by individuals or public authorities, we use the highest-level corporate owner as the global owner. ${ }^{15}$

This results in a sample of 322,525 individual corporate entities in 29,984 groups. Table 1 shows the basic sample allocated into broad country groups. The columns depict the location of the respective subsidiary, while the rows show the location of the owner. It becomes evident that Orbis data is dominated by European companies, and that there is very little information about developing countries. Nevertheless, this is still the most comprehensive dataset with which to investigate the question at hand.

All databases from Bureau van Dijk including Orbis provide information about the last ten years. Given that accounts are reported with some delay and the information for the year 2012 is still incomplete, this implies that we can use a time window of nine years, namely from 2003 to 2011 . However, for some companies not all the necessary information is available for all years. To maximise the coverage we calculate the resulting tax base allocation for each factor separately, which results in different sample sizes for the different variables.

\footnotetext{
14 The 100 million companies also include a large number of public authorities, e.g. universities or hospitals, which are not relevant for the purpose of our analysis. For comparison, OpenCorporates.com has data on 62 million companies (as at 7 January 2014).

15 It is noteworthy that Bureau Van Dijk only reports the ownership information on a cross-sectional basis. This implies that newer ownership information replaces previous information, and all the information about the group structure is based on the information available at the time of the download (Autumn 2013).
} 
Table 1 Number of firms in MNE groups, by location and owner country groups

\begin{tabular}{|c|c|c|c|c|c|c|c|c|c|c|c|}
\hline & $\begin{array}{r}\text { European } \\
\text { Union }\end{array}$ & $\begin{array}{r}\text { Other } \\
\text { Europe }\end{array}$ & $\begin{array}{r}\text { North } \\
\text { America }\end{array}$ & Asia & Australasia & $\begin{array}{r}\text { Latin } \\
\text { America }\end{array}$ & Caribbean & $\begin{array}{r}\text { Central } \\
\text { American }\end{array}$ & $\begin{array}{l}\text { North Africa } \\
\text { Middle East }\end{array}$ & $\begin{array}{r}\text { Sub-Saharan } \\
\text { Africa }\end{array}$ & Total \\
\hline European Union & 177,275 & 10,246 & 9,025 & 2,651 & 387 & 1,326 & 23 & 10 & 632 & 138 & 201,713 \\
\hline Other Europe & 8,785 & 11,742 & 908 & 342 & 71 & 100 & 4 & 2 & 57 & 8 & 22,019 \\
\hline North America & 27,736 & 1,165 & 23,095 & 1,997 & 366 & 767 & 23 & 13 & 113 & 12 & 55,287 \\
\hline Asia & 7,220 & 502 & 4,218 & 19,585 & 204 & 198 & 40 & 3 & 67 & 11 & 32,048 \\
\hline Australasia & 1,529 & 52 & 406 & 145 & 384 & 32 & 3 & 0 & 4 & 2 & 2,557 \\
\hline Latin America & 324 & 13 & 137 & 11 & 3 & 512 & 1 & 4 & 2 & 5 & 1012 \\
\hline Caribbean & 3,055 & 424 & 396 & 393 & 24 & 49 & 89 & 5 & 2 & 2 & 4,439 \\
\hline Central American & 83 & 11 & 23 & 1 & 0 & 2 & 2 & 8 & 0 & 0 & 130 \\
\hline $\begin{array}{l}\text { North Africa/Middle } \\
\text { East }\end{array}$ & 1,633 & 126 & 257 & 36 & 5 & 14 & 0 & 0 & 522 & 1 & 2,594 \\
\hline Sub-Saharan Africa & 571 & 19 & 40 & 19 & 15 & 17 & 1 & 0 & 3 & 41 & 726 \\
\hline Total & 228,211 & 24,300 & 38,505 & 25,180 & 1,459 & 3,017 & 186 & 45 & 1,402 & 220 & 322,525 \\
\hline
\end{tabular}

Notes: The columns describe the region in which the subsidiary is located, while the rows describe the region of the group headquarters. 
Table 2 reports the basic statistics for the profit measure and the apportionment factors used. Overall we have the necessary information for about 200,000 distinct companies in more than 26,000 groups. Only for payroll does the number of companies covered fall significantly, to 147,054 companies. ${ }^{16}$

Table 2 Descriptive statistics profit and loss and apportionment factors

\begin{tabular}{lrrrrrrr}
\hline & Observations & Mean & $\begin{array}{r}\text { Standard } \\
\text { deviation }\end{array}$ & Minimum & Maximum & $\begin{array}{r}\text { Distinct } \\
\text { companies }\end{array}$ & $\begin{array}{r}\text { Distinct } \\
\text { groups }\end{array}$ \\
\hline Profit/loss before taxes & $1,363,640$ & 9.84 & 716.00 & -76800.00 & $763,000.00$ & 211,448 & 26,801 \\
Turnover & $1,241,751$ & 118.00 & 1240.00 & 0.00 & $352,000.00$ & 198,288 & 26,341 \\
Tangible assets & $1,272,769$ & 26.10 & 575.00 & 0.00 & $453,000.00$ & 199,844 & 26,397 \\
Total assets & $1,359,831$ & 513.00 & 11200.00 & 0.00 & $2,480,000.00$ & 211,360 & 26,795 \\
Payroll & 911,999 & 11.80 & 87.80 & 0.00 & $17,100.00$ & 147,054 & 23,824 \\
No. of employees & $1,021,917$ & 244.15 & 2321.996 & 0.00 & $961,000.00$ & 182,481 & 25,393 \\
Taxation & $1,241,044$ & 1.69 & 63.8 & -5310 & $42,700.00$ & 201,583 & 26,460 \\
\hline
\end{tabular}

Notes: All values except number of employees and the number of companies and groups are in million USD. All observations with negative values for the apportionment factors are dropped.

The use of this dataset has at least two relevant dimensions, along which a selection bias can occur. The first occurs when specific types of companies (e.g. companies in low-tax countries, or very large or very profitable ones) are either not included in the database at all, or have missing or false ownership information. The second occurs when specific companies do not report the variables necessary for our analysis. While it is difficult to judge whether the overall coverage is good and whether ownership information is reliable, we can at least investigate the relative coverage across countries to see whether there is a strong selection in terms of coverage. While for most factors the number of companies dropping out from the initial sample is evenly distributed across countries, there appears to be a relevant bias for the employment and payroll factor. For the latter this becomes very evident with a few countries dropping out completely because of insufficient payroll numbers being reported.

Particular issues arise with using Orbis to look across countries at different income levels (rather than, for example, comparing within the EU only). One is that the requirements of financial accounting may be more variable. Another is that many developing countries use tax holidays or special rates to a greater extent than industrialised countries, and so it is not always clear to what extent lower tax revenue may be due to a small tax base or to a low (preferential) rate being applied. Since there is no plausible way to infer from financial accounts the applied tax rate, we first circumvent this problem by only analysing how the corporate tax base would be affected. In a second step we use the reported tax payments as the starting point for the tax base, at the potential cost of significant measurement errors.

\subsection{Empirical approach}

To simulate the tax base effect of a move to unitary taxation with formula apportionment we need information about the tax base under separate accounting $\left(\Pi_{j, t}^{S A}\right)$, the tax base under unitary taxation $\left(\Pi_{j, t}^{U T}\right)$ and the apportionment factors $\left(\theta_{i j X}\right)$. The simplest way to measure the tax base is to use profit and loss before tax (PLBT) as reported in the accounts. In order to account for the possibility of domestic loss consolidation and loss carry forwards, we aggregate $P L B T$ at the country-firm level and carry the losses forward to be set off against future profits as in equation (7). Similarly we aggregate PLBT at the firm level and carry

16 In order to minimise further attrition of the database we linearly interpolate missing values before we calculate the hypothetical loss carry forward. We also set the initial stock of losses brought into the first period as zero. 
remaining losses forward as in equation (8). The main alternative tax base measure is derived from reported tax payments in the accounts. In line with the approach in Devereux and Loretz (2008), we define the tax base as the positive tax payments divided through the statutory corporate tax rate. In the case of a non-positive tax payment, we use the lower value of earnings before interest and taxation $(E B I T)$ and the ratio between the tax payment and the statutory tax rate.

For the apportionment factors we use total assets (ASSETS) and tangible assets (TANG) as a measure for capital invested, turnover (TURN) as a proxy for sales by origin, the number of employees (EMP) and the cost of employees (PAY) as employment factors. ${ }^{17}$ For the twopart approach by Avi-Yonah et al (2009), we define operating expenses as the difference between TURN and EBIT. After assuming a one (five) per cent ordinary return, we apportion the excess profits according to ASSETS.

The lack of coverage for lower-income countries, the absence of any information about sales by destination, and comparison with the results of Shackelford and Slemrod (1998) and Clausing and Lahav (2009), are the main motives for also using consolidated data. The International Financial Reporting Standards require large companies to provide segmental reporting along business lines and geographical markets. Unfortunately the geographic reporting is not standardised, so it is not feasible to use the full geographic breakdown. Nevertheless, for 3,667 corporations in 32 different countries we are able to identify the proportion of profits, sales and assets in the domestic segment. Then we compare the profits reported in the home country to the profits which would be allocated to the home country if sales or assets had been used as an apportionment factor.

\section{Empirical results}

\subsection{Tax base effects}

This section presents some of the basic results. For reasons of space we only present the country-by-country results for the largest sample with formula apportionment according to total assets. For all other apportionment factors the detailed results can be found in the Appendix Tables, having the same structure. To give an indication of the representativeness of the results, the first column presents the average number of firms the results are based on. The next column presents the simple sum of profit and loss before taxes in the country, reported in million USD. This is the sum over all firms located in this country and over the years 2003 through to 2011. The third column presents the percentage change if we adjust the sum of the profit and loss measure for domestic group relief and loss carry forward. Specifically, we aggregate profits and losses within the same country, and we carry remaining losses forward and set them off against profits in the next periods. The last two columns present the core results of this paper, namely the impact on the corporate tax base through a move to unitary taxation and apportionment. To separate partly the effects of loss consolidation and apportionment, we compare the allocated tax base under unitary taxation first to the simple sum of profit and losses in [2], and then to the tax base measure which is already adjusted for loss carry forward and group relief within the same country in [3].

Table 3 reports the baseline results for total assets as apportionment factor. The rather large and positive changes in column [3] show that losses played a significant role in the period investigated. Compared to simply aggregating profit and losses before taxation in column [2],

All the proposals and existing systems have sales by destination rather than sales by origin as an apportionment factor. Since we are not able to obtain sales by destination and also cannot distinguish between inter-company and customer sales, we have to rely on turnover as a proxy for the sales factor. 
the modelling of group relief and loss carry forward increases the measure of the corporate tax base significantly. The simple sum of profit and losses in column [2] would imply an immediate recognition of tax losses, which is clearly not realistic. Therefore we think that column [3] is a more realistic benchmark. Nevertheless the comparison between the two measures gives an indication of the extent to which the treatment of losses matters. China and Greece are clearly outliers because some of the largest losses in our dataset are reported in a Chinese subsidiary and a Greek bank, but overall the loss consolidation or carry forward makes up a significant share. ${ }^{18}$ Even for countries where the coverage is broad and therefore a few large loss-making companies should matter less, the modelling of loss carry forward increases the tax base measure by 20 per cent (France) to 30 per cent (United Kingdom).

Concerning the change from separate accounting to unitary taxation with apportionment according to total assets, the results in column [5] surprisingly show that primarily Belgium will gain corporate tax base on a large scale, while most other countries lose compared to the scenario in column [3]. This again highlights that in the period observed losses are playing an important role. While the positive results in column [3] indicate that there are a lot of losses which can not be offset within the own country and therefore are only carried forward, the primarily negative result in column [5] tells a story that group-wide consolidation under unitary taxation would allow firms to use at least a part of the losses currently trapped in individual countries. Thus the effect of international loss consolidation will on average shrink significantly - by 13.4 per cent - the overall tax base available to distribute.

Multinational groups would experience a corresponding reduction in the disincentive to make risky investments in new countries that results from current arrangements. 
Table 3 Baseline results for total assets as apportionment factor

\begin{tabular}{|c|c|c|c|c|c|}
\hline & \multirow{2}{*}{$\begin{array}{r}\text { No. } \\
\text { firms }\end{array}$} & \multirow{2}{*}{$\begin{array}{l}\text { Sum profit and } \\
\text { loss before taxes }\end{array}$} & \multirow{2}{*}{$\begin{array}{r}\% \text { change through } \\
\text { group relief and } \\
\text { losses carried } \\
\text { forward }\end{array}$} & \multicolumn{2}{|c|}{$\%$ change under unitary taxation } \\
\hline & & & & Relative to [2] & $\begin{array}{l}\text { Relative to tax base } \\
\text { measure underlying }\end{array}$ \\
\hline & [1] & [2] & [3] & [4] & [5] \\
\hline Argentina & 15 & 679.31 & $36.6 \%$ & $164.1 \%$ & $93.3 \%$ \\
\hline Australia & 233 & $248,254.49$ & $7.5 \%$ & $7.5 \%$ & $0.0 \%$ \\
\hline Austria & 2,376 & $136,956.72$ & $22.1 \%$ & $-1.4 \%$ & $-19.2 \%$ \\
\hline Belgium & 6,178 & $305,520.39$ & $33.3 \%$ & $78.5 \%$ & $33.9 \%$ \\
\hline Bosnia Herzegovina & 217 & 964.58 & $73.2 \%$ & $78.7 \%$ & $3.2 \%$ \\
\hline Brazil & 228 & $84,875.08$ & $6.1 \%$ & $-28.6 \%$ & $-32.7 \%$ \\
\hline Bulgaria & 559 & $12,552.12$ & $23.8 \%$ & $-0.5 \%$ & $-19.6 \%$ \\
\hline Chile & 20 & $38,317.72$ & $0.5 \%$ & $-72.3 \%$ & $-72.4 \%$ \\
\hline China & 754 & $22,501.51$ & $305.4 \%$ & $254.9 \%$ & $-12.5 \%$ \\
\hline Colombia & 299 & $30,024.14$ & $5.5 \%$ & $-14.2 \%$ & $-18.7 \%$ \\
\hline Croatia & 870 & $13,146.01$ & $32.7 \%$ & $-12.8 \%$ & $-34.3 \%$ \\
\hline Cyprus & 10 & $3,175.48$ & $2.1 \%$ & $-35.0 \%$ & $-36.3 \%$ \\
\hline Czech Republic & 3,842 & $96,163.61$ & $10.9 \%$ & $-30.6 \%$ & $-37.5 \%$ \\
\hline Denmark & 2,411 & $137,370.11$ & $27.6 \%$ & $13.9 \%$ & $-10.8 \%$ \\
\hline Estonia & 1,074 & $11,977.64$ & $14.0 \%$ & $-29.9 \%$ & $-38.5 \%$ \\
\hline Finland & 3,059 & $106,247.17$ & $21.3 \%$ & $-4.2 \%$ & $-21.0 \%$ \\
\hline France & 23,109 & $1,390,729.50$ & $20.6 \%$ & $6.8 \%$ & $-11.4 \%$ \\
\hline Germany & 11,153 & $772,192.12$ & $30.6 \%$ & $17.8 \%$ & $-9.8 \%$ \\
\hline Greece & 899 & $1,044.08$ & $4,302.7 \%$ & $3,319.5 \%$ & $-22.3 \%$ \\
\hline Hungary & 769 & $89,504.92$ & $10.1 \%$ & $-59.5 \%$ & $-63.2 \%$ \\
\hline Iceland & 114 & $-7,195.50$ & $-163.5 \%$ & $-145.0 \%$ & $-29.1 \%$ \\
\hline India & 336 & $22,738.74$ & $32.3 \%$ & $-23.4 \%$ & $-42.1 \%$ \\
\hline Indonesia & 12 & 0.00 & $0.0 \%$ & $1,283.33$ & $1,283.33$ \\
\hline Ireland & 2,080 & $81,212.61$ & $134.3 \%$ & $123.8 \%$ & $-4.5 \%$ \\
\hline Italy & 11,682 & $387,360.13$ & $50.2 \%$ & $42.4 \%$ & $-5.2 \%$ \\
\hline Japan & 4,642 & $522,716.17$ & $4.9 \%$ & $-2.8 \%$ & $-7.3 \%$ \\
\hline Kazakhstan & 69 & $3,050.68$ & $44.0 \%$ & $-72.3 \%$ & $-80.7 \%$ \\
\hline Latvia & 398 & $1,569.92$ & $210.6 \%$ & $111.5 \%$ & $-31.9 \%$ \\
\hline Lithuania & 382 & $8,087.82$ & $28.8 \%$ & $10.4 \%$ & $-14.2 \%$ \\
\hline Luxembourg & 929 & $123,380.03$ & $93.2 \%$ & $99.5 \%$ & $3.2 \%$ \\
\hline Macedonia & 13 & 368.28 & $16.1 \%$ & $-41.1 \%$ & $-49.2 \%$ \\
\hline Malta & 135 & $18,844.27$ & $19.1 \%$ & $-24.8 \%$ & $-36.9 \%$ \\
\hline Mexico & 193 & $35,743.75$ & $21.7 \%$ & $-49.1 \%$ & $-58.2 \%$ \\
\hline Montenegro & 12 & 231.01 & $79.3 \%$ & $32.2 \%$ & $-26.2 \%$ \\
\hline Netherlands & 4,157 & $673,708.62$ & $25.7 \%$ & $13.9 \%$ & $-9.4 \%$ \\
\hline New Zealand & 99 & $3,544.38$ & $8.9 \%$ & $-23.0 \%$ & $-29.3 \%$ \\
\hline Norway & 6,061 & $435,510.78$ & $11.6 \%$ & $-11.1 \%$ & $-20.3 \%$ \\
\hline Peru & 49 & $18,011.34$ & $0.6 \%$ & $-38.2 \%$ & $-38.5 \%$ \\
\hline Philippines & 165 & $10,799.52$ & $7.0 \%$ & $-19.8 \%$ & $-25.0 \%$ \\
\hline Poland & 4,490 & $157,218.02$ & $15.0 \%$ & $-23.5 \%$ & $-33.5 \%$ \\
\hline Portugal & 2,356 & $108,700.20$ & $18.1 \%$ & $-4.5 \%$ & $-19.2 \%$ \\
\hline Romania & 2,476 & $27,036.24$ & $54.2 \%$ & $15.6 \%$ & $-25.0 \%$ \\
\hline Russia & 2,964 & $349,608.91$ & $6.8 \%$ & $-14.8 \%$ & $-20.2 \%$ \\
\hline Serbia & 897 & $2,685.57$ & $249.7 \%$ & $166.9 \%$ & $-23.7 \%$ \\
\hline Singapore & 400 & $168,812.62$ & $3.3 \%$ & $-22.2 \%$ & $-24.6 \%$ \\
\hline Slovak Republic & 891 & $26,241.98$ & $24.0 \%$ & $0.5 \%$ & $-18.9 \%$ \\
\hline Slovenia & 214 & $5,228.90$ & $46.1 \%$ & $57.0 \%$ & $7.5 \%$ \\
\hline South Korea & 1,058 & $455,117.80$ & $8.6 \%$ & $-2.2 \%$ & $-9.9 \%$ \\
\hline Spain & 11,038 & $562,483.36$ & $31.9 \%$ & $5.6 \%$ & $-19.9 \%$ \\
\hline Sweden & 4,846 & $381,676.92$ & $28.6 \%$ & $2.8 \%$ & $-20.1 \%$ \\
\hline Switzerland & 129 & $61,223.95$ & $10.9 \%$ & $4.2 \%$ & $-6.0 \%$ \\
\hline Taiwan & 155 & $110,691.72$ & $15.6 \%$ & $12.1 \%$ & $-3.0 \%$ \\
\hline Turkey & 87 & $37,827.49$ & $3.7 \%$ & $-29.2 \%$ & $-31.7 \%$ \\
\hline Ukraine & 874 & $30,103.59$ & $22.0 \%$ & $-20.0 \%$ & $-34.4 \%$ \\
\hline United Kingdom & 29,166 & $3,778,569.50$ & $51.2 \%$ & $28.3 \%$ & $-15.2 \%$ \\
\hline United States & 668 & $220,764.94$ & $7.4 \%$ & $-6.8 \%$ & $-13.2 \%$ \\
\hline Total & 152,313 & $12,325,871.00$ & $32.5 \%$ & $14.7 \%$ & $-13.4 \%$ \\
\hline
\end{tabular}

Notes: No. firms refers to the average (over the period 2003-2011) number of firms these results are based on. All countries with less than 10 firms on average in all apportionment factors are excluded. Sum profit and loss refers to the simple sum of profit and loss before taxes and is reported in million USD. In the case of Indonesia, the total amount allocated to the country is reported in the Table. 
Put differently, countries with a decrease of less than 13.4 per cent will be relative winners. For the results in Table 3, the list of relative winners includes mostly the high tax countries like Italy, Japan and the United States, indicating that these countries are suffering from profit shifting under the current system of separate accounting. Like the surprise winner Belgium, there are some further results that are worth mentioning. Luxembourg and Ireland are relative winners compared to their European peers, as is Singapore compared to the major economies of Brazil and Mexico. This is most likely due to the fact that 'total assets' includes intangible assets, and most importantly financial assets. Since these two types of assets are used to a non-negligible extent to move profits to more favourable tax jurisdictions, this also explains that the redistribution of the corporate tax base is less pronounced than for the other apportionment factors.

On a different note, if the apportionment factor results in redistribution into countries with significantly higher tax rates, this could also result in higher overall tax revenue. However, due to restrictions on the availability of reliable tax rate information, we have not yet investigated the tax revenue consequences. In the next subsection we will use a different tax base measure to investigate revenue impacts inclusive of the impact of reallocation to higher tax countries.

One immediate concern is the role played by losses during the recent financial crisis. The results in Table 3 refer to a period of nine years. To investigate whether single crisis years are driving the results, Figure 1 shows a box plot over the country-years. Each box plot shows the interquartile range of the ratio of the tax base allocated under unitary taxation and the tax base allocated under separate accounting, corresponding to the results in column [5]. The line inside the box marks the median result and the whiskers are at 1.5 times the interquartile range. Yearly values outside this range are displayed as dots. For some countries some yearly results are very high and the graph would be difficult to present. Since these graphs are for illustrative purposes only, we have set values above 100 per cent to 100 per cent. In the case of apportionment by total assets this is only relevant for some observations in Argentina and Montenegro. The red line represents the overall average, so all results above the red line present a country being a relative winner under unitary taxation.

Figure 1 confirms the claim that for most countries the overall result is not driven by extreme results during the crisis years. As mentioned above, the two most notable countries where single years with extreme losses dominate the results are China and Iceland. This is visible through the fact that there are both positive and negative outliers present. 


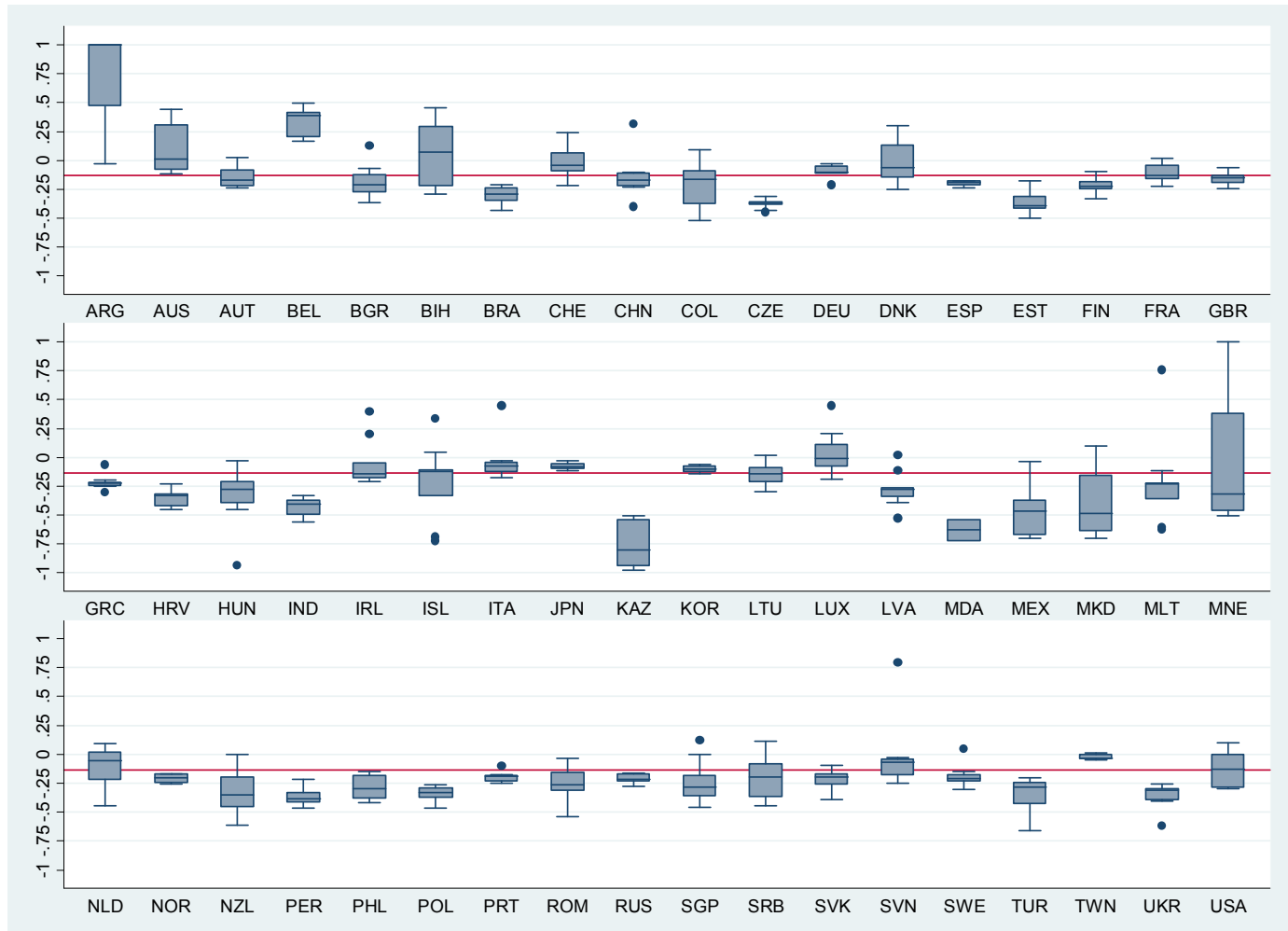

Figure 1 Tax base allocation over time: apportionment by total assets

Next we discuss the results for the different apportionment factors. In order to use as much of the information as possible, we first simulate the tax revenue effect for each of the apportionment factors separately. The detailed results of these simulations can be found in Appendix Tables A1-A6.

In the case of tangible assets as apportionment factor, the coverage is only slightly reduced and the overall reduction in the tax base of 13.4 per cent remains unchanged. However, the distributional effects are markedly different from the scenario in Table 3. Belgium is no longer the only relevant gaining country, but rather is in line with most established European economies losing tax base to Eastern European countries like Bulgaria, Bosnia Herzegovina, Czech Republic, Estonia, Latvia, Lithuania and Poland. In fact the only notable exception in Eastern Europe is Hungary, which loses significantly. A result worth mentioning is that Switzerland is among the winners, albeit with a very small number of companies backing up this result. The case of the large reported losses in China is now even more evident, since the simple sum of the profit and losses is negative. These large losses are offset to a large extent against taxable profits in the US, resulting in a substantial loss of tax base to the United States.

Using turnover as apportionment factor the sample size is slightly further reduced but the overall picture regarding the losses and the overall reduction of the tax base is broadly the same, with an overall reduction of 10.6 per cent due to international loss consolidation. Interestingly the picture from the result with total assets is restored, with high tax countries like the United States, Japan and Italy gaining tax base. At the same time the result that some of the established European countries lose to Eastern European countries is less pronounced. Countries that are commonly associated with a favourable tax system, like Luxembourg, Ireland, the Netherlands, Belgium and Switzerland, are now all seen to lose tax base. The Swiss case should again be treated with caution due to the small number of observations. 
The results for the number of employees as apportionment factor are based on a roughly 10 per cent smaller sample with approximately 117,000 individual firms. Nevertheless, the international loss consolidation still implies an overall reduction to the tax base of about 12 per cent, in line with previous results. Appendix Table A3 shows that basing the apportionment on the number of employees has vast redistributive consequences. By and large all the emerging economies gain a significant proportion of tax base, while some of the large established economies, such as Germany, France and the United States, lose significantly. Again, those jurisdictions with favourable tax treatment, like the Netherlands, Singapore, Ireland, Belgium, and Switzerland, are among the countries losing the largest share of their tax base.

The results for apportionment according to the cost of employees suffer from the problem that payroll data is not available for some countries like the United States, Mexico, China, Singapore, Russia and Australia, and hence the sample is reduced to about 100,000 firms on average. The reduction is even more pronounced in the sum of profit and losses, which now make up only half of the sum of the baseline case in Table 3 (where total assets is used as the apportionment factor). For this reason, direct comparisons to the previous results need to be treated cautiously. The next subsection shows the results of re-running the analysis with a subsample for which all the apportionment factors are reported, to allow a direct comparison. Nevertheless, the main change here, compared to previous results, is that less of the Eastern European countries turn out to be winning (unsurprisingly, since these countries typically have lower wages). This is in particular true for countries like Romania or Bulgaria. Among the few countries winning with cost of employees as apportionment factor is Italy.

For the two-part apportionment mechanism proposed by Avi-Yonah et al (2009), a fixed rate of return is first applied to the operating expenses in each country. In the second step the residual profit is allocated among countries using an apportionment factor. Note that the results here are a strong simplification from the original proposal, which is designed to be applied on a case-by-case basis. Due to data limitations it is not possible to identify the separate business lines as would be required for such an application, and therefore these results should only be seen as a first approximation to the proposal of Avi-Yonah et al. (2009). Significant further work would be necessary to provide a direct application. For our simulation we first use a 1 per cent return on expenses, and then allocate the residual profit according to the country shares of total assets. The overall change in the tax base is in line with the other apportionment factors (a reduction of 11.4 per cent). The United States, Japan and Italy are among the winners. More surprising is that most of the Eastern European countries lose significantly. This is slightly reversed once a 5 per cent return on expenses is assumed. In this case the overall reduction of the tax base is somewhat smaller, with only 10.5 per cent reduction.

Next, to compare directly the different apportionment factors we restrict our sample to those firms where we have the necessary information for all apportionment factors. This reduces the number of firms to a sample of 85,986 firms on average. The overall impact of lossmaking companies is comparable to the individual results above, with a reduction of 11.7 per cent of the overall tax base.

The most striking feature in Table 4 is that the differences between the various apportionment factors are very pronounced. Even for countries with relatively good coverage like Germany, Italy, France and the United Kingdom, the results differ significantly depending on the factor used to apportion the tax base. Further it is striking that total assets affects the relative distribution of the tax base the least, most likely due to the above-mentioned fact that total assets include financial and intangible assets which are partly used to relocate profits under the current system. 
Table 4 Baseline results for different apportionment factors

\begin{tabular}{|c|c|c|c|c|c|c|c|c|c|}
\hline \multirow[b]{2}{*}{ Country } & \multirow{2}{*}{$\begin{array}{r}\text { No. } \\
\text { firms }\end{array}$} & \multirow{2}{*}{$\begin{array}{r}\text { Sum } \\
\text { profit and loss } \\
\text { before taxes }\end{array}$} & \multicolumn{7}{|c|}{$\%$ change under unitary taxation, apportioned by } \\
\hline & & & Total assets & $\begin{array}{r}\text { Tangible } \\
\text { assets }\end{array}$ & Turnover & No. employees & Payroll & $\begin{array}{c}\text { Avi-Yonah } \\
1 \% \text { return }\end{array}$ & $\begin{array}{r}\text { Avi-Yonah } 5 \% \\
\text { return }\end{array}$ \\
\hline Austria & 1,040 & $71,153.69$ & $-21.3 \%$ & $-31.4 \%$ & $-21.7 \%$ & $-34.4 \%$ & $-19.7 \%$ & $-20.7 \%$ & $-17.6 \%$ \\
\hline Belgium & 4,296 & $293,037.10$ & $29.7 \%$ & $-48.6 \%$ & $-24.8 \%$ & $-46.5 \%$ & $-30.1 \%$ & $24.7 \%$ & $6.0 \%$ \\
\hline Bosnia Herzegovina & 185 & 442.32 & $-7.2 \%$ & $165.9 \%$ & $17.1 \%$ & $195.8 \%$ & $24.0 \%$ & $-5.7 \%$ & $1.6 \%$ \\
\hline Bulgaria & 491 & $7,866.76$ & $-19.3 \%$ & $23.3 \%$ & $-15.2 \%$ & $67.4 \%$ & $-31.7 \%$ & $-18.8 \%$ & $-16.1 \%$ \\
\hline Croatia & 784 & $6,741.58$ & $-20.3 \%$ & $4.8 \%$ & $-13.1 \%$ & $10.9 \%$ & $-17.1 \%$ & $-20.2 \%$ & $-19.1 \%$ \\
\hline Czech Republic & 3,145 & $67,705.02$ & $-25.5 \%$ & $28.4 \%$ & $-6.5 \%$ & $31.4 \%$ & $-26.4 \%$ & $-24.1 \%$ & $-18.6 \%$ \\
\hline Denmark & 1,365 & $65,639.08$ & $-19.2 \%$ & $-27.9 \%$ & $-23.0 \%$ & $-24.4 \%$ & $-18.4 \%$ & $-19.6 \%$ & $-21.0 \%$ \\
\hline Estonia & 698 & $6,248.35$ & $-22.1 \%$ & $7.1 \%$ & $-13.6 \%$ & $73.2 \%$ & $-23.6 \%$ & $-21.8 \%$ & $-19.5 \%$ \\
\hline Finland & 2,337 & $63,196.36$ & $-25.6 \%$ & $-24.5 \%$ & $-14.9 \%$ & $-15.6 \%$ & $-15.4 \%$ & $-25.1 \%$ & $-22.7 \%$ \\
\hline France & 16,707 & $752,573.14$ & $-17.5 \%$ & $-17.3 \%$ & $-11.8 \%$ & $-24.8 \%$ & $-6.8 \%$ & $-16.8 \%$ & $-13.8 \%$ \\
\hline Germany & 4,480 & $562,141.18$ & $-24.1 \%$ & $-30.5 \%$ & $-14.5 \%$ & $-23.5 \%$ & $-12.4 \%$ & $-23.1 \%$ & $-18.7 \%$ \\
\hline Hungary & 403 & $16,094.57$ & $-15.7 \%$ & $26.5 \%$ & $-6.2 \%$ & $62.4 \%$ & $-22.2 \%$ & $-15.6 \%$ & $-13.9 \%$ \\
\hline Ireland & 702 & $37,917.33$ & $-12.2 \%$ & $-17.9 \%$ & $-18.4 \%$ & $-44.6 \%$ & $-48.2 \%$ & $-13.4 \%$ & $-16.8 \%$ \\
\hline Italy & 8,716 & $257,083.65$ & $-4.1 \%$ & $11.2 \%$ & $11.4 \%$ & $8.3 \%$ & $6.3 \%$ & $-2.9 \%$ & $2.0 \%$ \\
\hline Japan & 1,535 & $142,926.62$ & $-2.9 \%$ & $1.9 \%$ & $-2.0 \%$ & $-1.2 \%$ & $-10.8 \%$ & $-3.9 \%$ & $-3.7 \%$ \\
\hline Latvia & 27 & -369.76 & $51.3 \%$ & $91.5 \%$ & $10.1 \%$ & $116.5 \%$ & $-4.4 \%$ & $47.2 \%$ & $35.4 \%$ \\
\hline Luxembourg & 154 & $47,508.76$ & $-8.4 \%$ & $-76.5 \%$ & $-43.4 \%$ & $-81.2 \%$ & $-77.2 \%$ & $-11.8 \%$ & $-15.5 \%$ \\
\hline Netherlands & 775 & $91,369.11$ & $-26.5 \%$ & $-44.5 \%$ & $-32.4 \%$ & $-62.7 \%$ & $-61.2 \%$ & $-26.1 \%$ & $-23.5 \%$ \\
\hline Norway & 3,147 & $154,679.47$ & $-22.0 \%$ & $-10.9 \%$ & $-21.8 \%$ & $-26.6 \%$ & $-20.3 \%$ & $-22.1 \%$ & $-22.5 \%$ \\
\hline Poland & 2,504 & $67,735.79$ & $-30.7 \%$ & $33.3 \%$ & $-5.3 \%$ & $67.4 \%$ & $-31.6 \%$ & $-28.7 \%$ & $-20.4 \%$ \\
\hline Portugal & 1,636 & $73,624.67$ & $-13.3 \%$ & $-5.6 \%$ & $-11.0 \%$ & $-5.0 \%$ & $-11.9 \%$ & $-13.4 \%$ & $-13.7 \%$ \\
\hline Romania & 2,096 & $23,749.13$ & $-30.5 \%$ & $49.6 \%$ & $-7.1 \%$ & $160.0 \%$ & $-13.3 \%$ & $-29.8 \%$ & $-26.1 \%$ \\
\hline Serbia & 839 & $1,217.25$ & $-17.8 \%$ & $75.6 \%$ & $-12.7 \%$ & $91.0 \%$ & $5.7 \%$ & $-18.4 \%$ & $-19.2 \%$ \\
\hline Slovak Republic & 800 & $23,213.89$ & $-10.3 \%$ & $32.8 \%$ & $1.2 \%$ & $39.4 \%$ & $-8.9 \%$ & $-9.9 \%$ & $-7.6 \%$ \\
\hline Slovenia & 192 & $2,808.68$ & $-16.2 \%$ & $0.9 \%$ & $-12.5 \%$ & $-1.0 \%$ & $-12.7 \%$ & $-16.1 \%$ & $-15.6 \%$ \\
\hline South Korea & 793 & $90,274.47$ & $-18.3 \%$ & $-1.4 \%$ & $-13.2 \%$ & $-6.5 \%$ & $-25.7 \%$ & $-18.5 \%$ & $-18.6 \%$ \\
\hline Spain & 9,692 & $447,315.23$ & $-12.1 \%$ & $-7.6 \%$ & $-15.5 \%$ & $-12.1 \%$ & $-13.3 \%$ & $-12.4 \%$ & $-13.3 \%$ \\
\hline Sweden & 2,514 & $108,766.46$ & $-10.9 \%$ & $-19.3 \%$ & $-24.6 \%$ & $-29.4 \%$ & $-21.4 \%$ & $-11.9 \%$ & $-15.7 \%$ \\
\hline Switzerland & 20 & $1,423.89$ & $6.3 \%$ & $15.6 \%$ & $-18.7 \%$ & $-3.3 \%$ & $-1.2 \%$ & $-2.3 \%$ & $-20.8 \%$ \\
\hline Taiwan & 144 & $106,711.90$ & $-1.5 \%$ & $-1.6 \%$ & $-2.0 \%$ & $-2.1 \%$ & $-2.9 \%$ & $-1.6 \%$ & $-1.9 \%$ \\
\hline Ukraine & 807 & $29,419.52$ & $-39.8 \%$ & $-1.3 \%$ & $-19.2 \%$ & $89.2 \%$ & $-27.2 \%$ & $-38.9 \%$ & $-34.6 \%$ \\
\hline United Kingdom & 12,961 & $966,003.66$ & $-6.2 \%$ & $-0.5 \%$ & $-7.0 \%$ & $0.1 \%$ & $0.8 \%$ & $-6.0 \%$ & $-5.1 \%$ \\
\hline Total & 85,986 & $4,595,884.80$ & $-11.7 \%$ & $-11.8 \%$ & $-11.7 \%$ & $-11.8 \%$ & $-11.8 \%$ & $-11.7 \%$ & $-11.1 \%$ \\
\hline
\end{tabular}

Notes: No. firms refers to the average (over the period 2003 to 2011) number of firms these results are based on. All countries with less than 10 firms on average in all apportionment factors are excluded. Sum profit and loss refers to the simple sum of profit and loss before taxes and is reported in million USD. 
The choice of apportionment factors matters most to the lowest-income countries in the sample, those of Eastern Europe. Using tangible assets allocates more of the tax base to lower-income countries, and most countries of the region are major winners if number of employees is used. This result is largely reversed if the cost of employees is used as allocation factor.

Figure 2 illustrates the results from Table 4 following the same logic as Figure 1. Regardless of the apportionment factors chosen, countries like Luxembourg, Ireland and the Netherlands will see a significant share of their tax base allocated away from them - reflecting the disproportionally large share of the tax base these jurisdictions have been able to attract under the current system of separate accounting. ${ }^{19}$

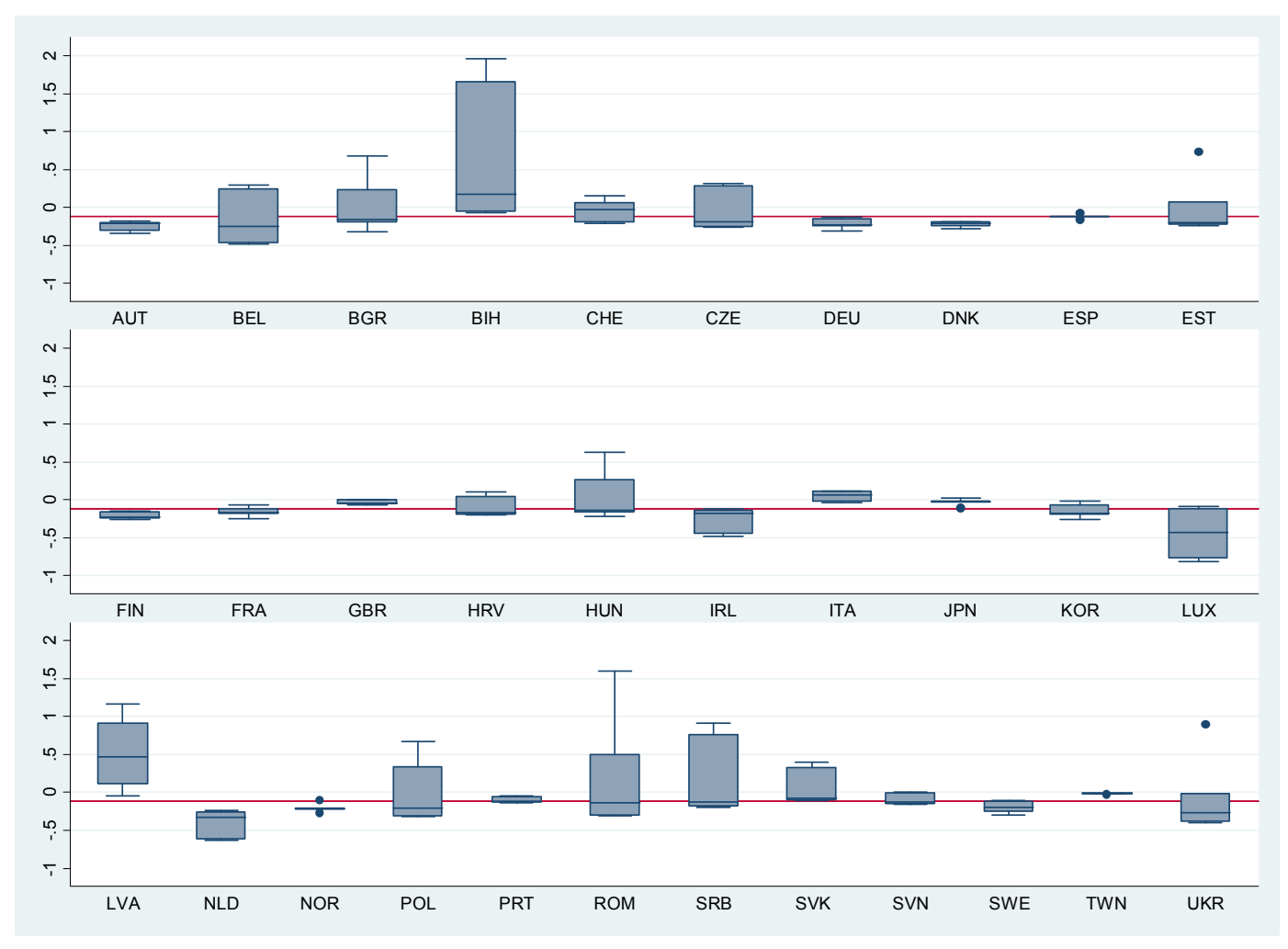

Figure 2 Tax base apportionment: variation across factors

Figure 3 shows the variation across countries for the different apportionment factors. Overall it is clear that the redistributive effects of apportionment are far greater for the relatively immobile factors - in particular, number of employees (including when compared to payroll), and tangible assets (including when compared to total assets).

19 We are grateful to Francis Weyzig for suggesting some caution here, since Orbis may include tax-exempt dividends from subsidiaries in its gross profit, and for some jurisdictions with many intermediate holdings such as Luxembourg and the Netherlands this may result in systematic overstating of profits under separate accounting. This caution is tempered by the fact that IMF (2014) identifies the same jurisdictions as among the 'conduit' group which they find would consistently lose tax base under any apportionment factor applied to taxation of US-headquartered multinationals. 


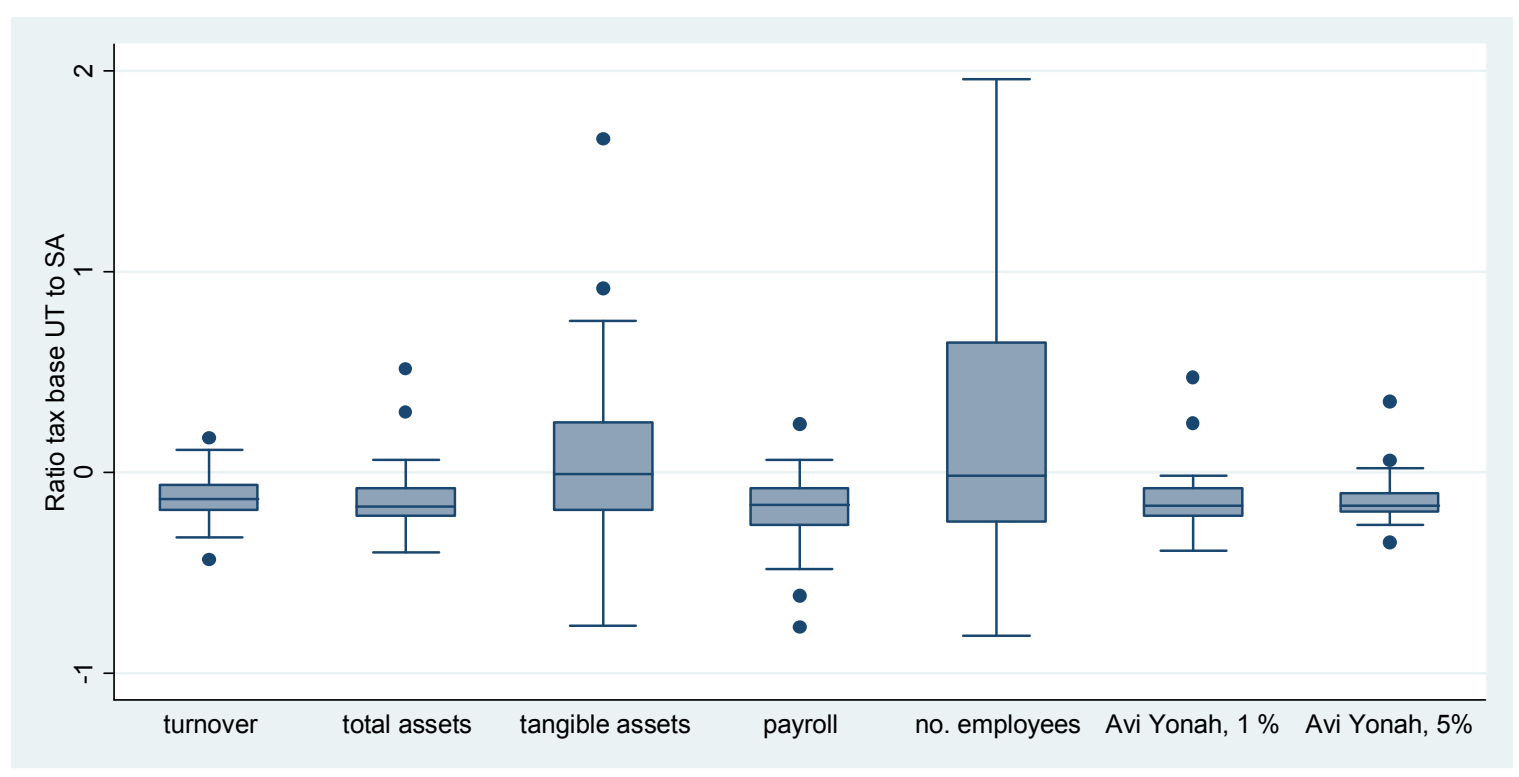

Figure 3 Tax base apportionment: variation across countries

\subsection{Tax revenue effects}

The analysis so far has concentrated on the distributional effects of unitary taxation on the corporate tax base. The question in the background that is really of interest is the difference in the extent to which countries would be able to raise tax revenue under the alternative system of unitary taxation. To get closer to the answer to this question we repeat the simulation exercise from above with a different tax base measure, based on the tax liabilities reported in the accounts. Then we compare the tax liabilities resulting from the allocated tax base to the sum of the tax liabilities reported under the current system. This approach is in line with the methodology of Devereux and Loretz (2008). Comparing the results to the previous results, one needs to bear in mind some caveats. First the tax base measure is now hinging on the assumption that the top statutory tax rate has been applied to all the taxable profits. Secondly we are now comparing our simulation results to the simple sum of reported tax liabilities - including negative tax liabilities - which implies that we treat negative tax liabilities as paid-out tax rebates. Third, in contrast to the results above, we are not trying to separate out the effects from international loss consolidation and loss carry forwards. ${ }^{20}$

Table 5 reports the results for our simulation of tax revenue distribution using the subsample of firms for which all the necessary data about tax liabilities and apportionment factors is available. Overall we find a slightly positive effect on tax revenue for all apportionment factors with the exception of number of employees. This is due to the fact that apportioning according to number of employees allocates a larger share of the tax base to lower-income and lower-tax countries in Eastern Europe.

Overall the results for tax liabilities largely confirm the findings from above. Countries with a favourable tax system like Ireland and the Netherlands lose tax revenue regardless of the apportionment factor/s chosen, while high-income and higher-tax countries like the United Kingdom and Spain win under all scenarios. For Bosnia Herzegovina and Serbia we get rather extreme positive results. This is most likely reflecting the fact that deriving a tax base measure based on tax liabilities divided by the statutory tax rate is subject to substantial measurement error in young nation states with generous tax holidays.

20 Doing so would put even more emphasis on our tax burden measure which hinges on the crucial assumption that all tax base is subject to the statutory tax rate. We have done this analysis and results show approximately a 7 per cent decrease in the benchmark tax base, changing the result to a larger positive effect overall. 
The other conclusion that can reliably be drawn is that the different apportionment factors result in very different distribution of tax liabilities. In line with our baseline results, apportionment by number of employees strongly favours lower-income countries, while apportionment by cost of employees allocates the tax base to the richer economies.

Our results are also broadly in line with the recent analysis of IMF (2014), which uses data on US-headquartered multinational groups to show a strong positive effect for emerging economies and developing countries (e.g. China, India and South Africa) when using employment as the apportionment factor. The IMF study also finds a group of consistent losers (regardless of apportionment factor), namely the conduit jurisdictions of Bermuda, Ireland, Luxembourg, Netherlands, Singapore and Switzerland. Once these are taken out of the analysis, advanced economies taken together see tax base increases of a quarter to a half, depending on the apportionment factor. 
Table 5 Results for tax reported, balanced subsample for different apportionment factors

\begin{tabular}{|c|c|c|c|c|c|c|c|c|c|}
\hline \multirow[t]{2}{*}{ Country } & \multirow{2}{*}{$\begin{array}{r}\text { No. } \\
\text { firms }\end{array}$} & \multirow{2}{*}{$\begin{array}{r}\text { Sum } \\
\text { reported } \\
\text { tax liabilities }\end{array}$} & \multicolumn{7}{|c|}{$\%$ change under unitary taxation, apportioned by } \\
\hline & & & Total assets & $\begin{array}{r}\text { Tangible } \\
\text { assets }\end{array}$ & Turnover & No. employees & Payroll & $\begin{array}{c}\text { Avi-Yonah } \\
1 \% \text { return }\end{array}$ & $\begin{array}{r}\text { Avi-Yonah } \\
5 \% \text { return }\end{array}$ \\
\hline Austria & 936 & $17,435.76$ & $-16.7 \%$ & $-24.4 \%$ & $-13.2 \%$ & $-33.6 \%$ & $-10.5 \%$ & $-16.1 \%$ & $-12.6 \%$ \\
\hline Belgium & 3,714 & $35,907.10$ & $145.9 \%$ & $2.1 \%$ & $51.6 \%$ & $0.7 \%$ & $28.7 \%$ & $132.3 \%$ & $90.8 \%$ \\
\hline Bosnia Herzegovina & 185 & 39.41 & $74.5 \%$ & $287.5 \%$ & $94.9 \%$ & $329.0 \%$ & $92.0 \%$ & $75.8 \%$ & $92.7 \%$ \\
\hline Bulgaria & 491 & $1,093.64$ & $-5.1 \%$ & $25.7 \%$ & $-7.6 \%$ & $65.9 \%$ & $-28.4 \%$ & $-6.0 \%$ & $-7.2 \%$ \\
\hline Croatia & 784 & $1,607.59$ & $-7.4 \%$ & $19.0 \%$ & $-0.9 \%$ & $23.1 \%$ & $-8.7 \%$ & $-7.7 \%$ & $-6.2 \%$ \\
\hline Czech Republic & 3,145 & $13,468.11$ & $-23.5 \%$ & $23.6 \%$ & $-7.2 \%$ & $24.9 \%$ & $-29.7 \%$ & $-21.6 \%$ & $-12.8 \%$ \\
\hline Denmark & 1,365 & $21,051.29$ & $-16.2 \%$ & $-28.2 \%$ & $-12.1 \%$ & $-20.1 \%$ & $-14.1 \%$ & $-16.6 \%$ & $-17.5 \%$ \\
\hline Estonia & 533 & 516.35 & $-1.5 \%$ & $14.5 \%$ & $-6.9 \%$ & $85.6 \%$ & $-19.5 \%$ & $-0.7 \%$ & $7.3 \%$ \\
\hline Finland & 2,122 & $11,499.48$ & $-13.8 \%$ & $-13.3 \%$ & $-6.5 \%$ & $-7.8 \%$ & $-7.3 \%$ & $-13.0 \%$ & $-7.7 \%$ \\
\hline France & 16,706 & $160,761.14$ & $4.4 \%$ & $4.5 \%$ & $12.5 \%$ & $-2.5 \%$ & $20.8 \%$ & $5.9 \%$ & $12.4 \%$ \\
\hline Germany & 4,249 & $141,524.73$ & $-14.8 \%$ & $-20.9 \%$ & $1.5 \%$ & $-14.6 \%$ & $-1.1 \%$ & $-13.1 \%$ & $-4.4 \%$ \\
\hline Hungary & 340 & $2,045.87$ & $-9.7 \%$ & $61.4 \%$ & $15.2 \%$ & $89.7 \%$ & $-7.7 \%$ & $-9.7 \%$ & $0.2 \%$ \\
\hline Ireland & 730 & $5,277.63$ & $-20.3 \%$ & $-33.2 \%$ & $-25.1 \%$ & $-55.2 \%$ & $-57.9 \%$ & $-20.8 \%$ & $-21.1 \%$ \\
\hline Italy & 8,716 & $138,309.47$ & $-12.2 \%$ & $-7.3 \%$ & $-4.6 \%$ & $-0.1 \%$ & $-2.1 \%$ & $-11.1 \%$ & $-6.1 \%$ \\
\hline Japan & 1,535 & $49,283.03$ & $1.8 \%$ & $5.6 \%$ & $0.4 \%$ & $4.8 \%$ & $-7.0 \%$ & $0.3 \%$ & $2.2 \%$ \\
\hline Latvia & 27 & 40.70 & $28.0 \%$ & $46.3 \%$ & $-10.5 \%$ & $42.5 \%$ & $-22.2 \%$ & $25.0 \%$ & $16.1 \%$ \\
\hline Luxembourg & 142 & $4,398.86$ & $101.9 \%$ & $-62.8 \%$ & $-6.9 \%$ & $-68.0 \%$ & $-63.6 \%$ & $87.0 \%$ & $63.0 \%$ \\
\hline Netherlands & 751 & $26,917.74$ & $-23.5 \%$ & $-24.4 \%$ & $-20.8 \%$ & $-60.7 \%$ & $-59.7 \%$ & $-23.2 \%$ & $-18.3 \%$ \\
\hline Norway & 3,147 & $55,837.13$ & $-27.1 \%$ & $-18.1 \%$ & $-34.4 \%$ & $-46.8 \%$ & $-39.4 \%$ & $-27.2 \%$ & $-27.6 \%$ \\
\hline Poland & 2,311 & $12,919.87$ & $-33.5 \%$ & $12.3 \%$ & $-14.1 \%$ & $75.3 \%$ & $-33.7 \%$ & $-31.0 \%$ & $-20.3 \%$ \\
\hline Portugal & 1,594 & $13,442.49$ & $-17.2 \%$ & $-8.1 \%$ & $-13.5 \%$ & $-6.2 \%$ & $-13.5 \%$ & $-17.4 \%$ & $-17.1 \%$ \\
\hline Romania & 2,096 & $6,718.75$ & $-29.2 \%$ & $27.3 \%$ & $-26.3 \%$ & $110.4 \%$ & $-14.8 \%$ & $-28.7 \%$ & $-25.5 \%$ \\
\hline Serbia & 839 & 227.88 & $144.5 \%$ & $365.5 \%$ & $113.2 \%$ & $406.3 \%$ & $166.4 \%$ & $140.0 \%$ & $132.0 \%$ \\
\hline Slovak Republic & 800 & $4,799.56$ & $-14.4 \%$ & $21.4 \%$ & $-8.1 \%$ & $26.9 \%$ & $-16.8 \%$ & $-14.0 \%$ & $-11.1 \%$ \\
\hline Slovenia & 158 & 650.42 & $-6.9 \%$ & $15.9 \%$ & $-3.5 \%$ & $10.3 \%$ & $-3.7 \%$ & $-6.6 \%$ & $-4.4 \%$ \\
\hline South Korea & 701 & $22,996.31$ & $-14.8 \%$ & $-2.6 \%$ & $-12.8 \%$ & $-6.6 \%$ & $-21.9 \%$ & $-14.9 \%$ & $-13.9 \%$ \\
\hline Spain & 9,083 & $99,009.29$ & $18.6 \%$ & $23.3 \%$ & $14.6 \%$ & $17.9 \%$ & $16.9 \%$ & $18.1 \%$ & $17.3 \%$ \\
\hline Sweden & 2,514 & $19,533.51$ & $6.3 \%$ & $-2.7 \%$ & $-6.2 \%$ & $-11.0 \%$ & $-2.6 \%$ & $4.2 \%$ & $-1.3 \%$ \\
\hline Switzerland & 18 & 213.86 & $5.6 \%$ & $29.6 \%$ & $-34.8 \%$ & $19.8 \%$ & $16.6 \%$ & $-6.8 \%$ & $-35.7 \%$ \\
\hline Taiwan & 144 & $12,900.70$ & $6.7 \%$ & $6.6 \%$ & $6.1 \%$ & $6.0 \%$ & $5.0 \%$ & $6.5 \%$ & $5.7 \%$ \\
\hline Ukraine & 807 & $10,098.12$ & $-40.5 \%$ & $-22.8 \%$ & $-31.8 \%$ & $21.3 \%$ & $-35.2 \%$ & $-39.9 \%$ & $-36.4 \%$ \\
\hline United Kingdom & 11,662 & $216,528.84$ & $11.6 \%$ & $17.2 \%$ & $7.5 \%$ & $17.1 \%$ & $19.9 \%$ & $11.9 \%$ & $13.7 \%$ \\
\hline Total & 82,345 & $1,107,054.60$ & $2.0 \%$ & $0.5 \%$ & $1.8 \%$ & $-0.2 \%$ & $2.3 \%$ & $2.0 \%$ & $4.1 \%$ \\
\hline
\end{tabular}

Notes: No. firms refers to the average (over the period 2003-2011) number of firms these results are based on. All countries with less than 10 firms on average in all apportionment factors are excluded. Sum reported tax liabilities refers to the simple sum of the tax liabilities in the accounts and is reported in million USD. 


\subsection{Results using segmental reporting}

Table 6 reports the results for our analysis of segmental reporting in the consolidated reports. In the spirit of Shakelford and Slemrod (1998), we only look at the profit share of the home country. Specifically we calculate how much of the profits would be allocated to the home country if the share of the profit in the home country is in line with the share of assets or sales in the home country.

Table 6 Results for profit allocation using segmental reporting

\begin{tabular}{|c|c|c|c|c|c|}
\hline \multirow[t]{2}{*}{ Country } & \multirow[t]{2}{*}{ No. firms } & \multirow[t]{2}{*}{ Observations } & \multirow[t]{2}{*}{ Sum of profits } & \multicolumn{2}{|c|}{$\%$ of profit allocated through } \\
\hline & & & & Sales factor & Assets factor \\
\hline Australia & 535 & 1,682 & $90,382.26$ & $90.3 \%$ & $89.4 \%$ \\
\hline Austria & 23 & 82 & $6,495.57$ & $111.4 \%$ & $99.9 \%$ \\
\hline Belgium & 16 & 60 & $5,100.46$ & $110.8 \%$ & $94.4 \%$ \\
\hline Canada & 224 & 847 & $83,509.59$ & $84.5 \%$ & $89.1 \%$ \\
\hline China & 14 & 30 & $5,578.79$ & $98.9 \%$ & $98.9 \%$ \\
\hline Finland & 17 & 74 & $2,891.00$ & $91.5 \%$ & $84.1 \%$ \\
\hline France & 123 & 389 & $140,939.60$ & $105.6 \%$ & $108.6 \%$ \\
\hline Germany & 91 & 285 & $86,096.82$ & $64.6 \%$ & $81.1 \%$ \\
\hline Greece & 34 & 108 & $11,485.55$ & $97.5 \%$ & $99.0 \%$ \\
\hline Hongkong & 55 & 202 & $51,369.61$ & $73.7 \%$ & $79.7 \%$ \\
\hline India & 54 & 134 & $9,386.00$ & $97.8 \%$ & $96.5 \%$ \\
\hline Indonesia & 42 & 141 & $16,962.06$ & $100.0 \%$ & $99.8 \%$ \\
\hline Ireland & 19 & 63 & $2,501.98$ & $97.9 \%$ & $58.5 \%$ \\
\hline Israel & 91 & 354 & $13,216.50$ & $63.9 \%$ & $88.7 \%$ \\
\hline Japan & 1,038 & 6,787 & $1,030,347.00$ & $93.6 \%$ & $97.6 \%$ \\
\hline Kenya & 11 & 53 & $1,255.62$ & $88.2 \%$ & $90.0 \%$ \\
\hline Kuwait & 41 & 124 & $7,212.39$ & $58.9 \%$ & $54.5 \%$ \\
\hline Malaysia & 209 & 697 & $20,335.22$ & $83.2 \%$ & $74.9 \%$ \\
\hline Netherlands & 22 & 104 & $16,155.52$ & $87.3 \%$ & $68.5 \%$ \\
\hline New Zealand & 46 & 236 & $8,940.33$ & $78.2 \%$ & $75.7 \%$ \\
\hline Norway & 21 & 64 & $4,283.28$ & $84.0 \%$ & $87.3 \%$ \\
\hline Oman & 10 & 27 & 281.22 & $101.1 \%$ & $113.2 \%$ \\
\hline Philipines & 13 & 49 & $3,025.44$ & $90.5 \%$ & $83.3 \%$ \\
\hline Singapore & 89 & 411 & $18,379.39$ & $71.9 \%$ & $69.0 \%$ \\
\hline South Africa & 76 & 256 & $51,065.13$ & $86.6 \%$ & $74.7 \%$ \\
\hline Sri Lanka & 10 & 62 & 654.80 & $126.5 \%$ & $101.2 \%$ \\
\hline Sweden & 46 & 143 & $5,018.42$ & $79.2 \%$ & $61.6 \%$ \\
\hline Switzerland & 16 & 46 & $159,352.90$ & $9.1 \%$ & $91.4 \%$ \\
\hline Taiwan & 217 & 1,106 & $14,703.73$ & $80.2 \%$ & $84.9 \%$ \\
\hline Thailand & 80 & 324 & $20,698.70$ & $91.9 \%$ & $79.8 \%$ \\
\hline Turkey & 13 & 38 & $2,224.60$ & $94.1 \%$ & $101.5 \%$ \\
\hline United Kingdom & 371 & 1,340 & $159,053.70$ & $105.7 \%$ & $100.8 \%$ \\
\hline Total & 3,667 & 16,318 & $2,048,903.18$ & $85.8 \%$ & $94.5 \%$ \\
\hline
\end{tabular}

Notes: Sum of profits refers to sum of profits in the home country and is in million USD.

Our result implies that the share of profits at home are on average 15 per cent higher than the share of sales at home, and about 5 per cent higher than assets. This is in stark contrast to the results of Shackelford and Slemrod (1998), who find a disproportionately large share of the tax base of US multinationals abroad.

This difference is most likely due to the fact that we use the profit measure from the segmental reports, while Shackelford and Slemrod (1998) infer the taxable income from the footnotes of the tax provisions. It is also possible, however, that particular differences in the US approach (e.g. to worldwide corporate income taxation, and the tax implications of profit repatriation) result in US-headquartered multinationals displaying some important differences in tax behaviour from others. Apart from the unrealistic outlier Switzerland in the case of the sales factor, the usual suspects of Ireland and Singapore are seen to lose a large share of their profits. However, the overall results are mainly driven by Japan, which makes up onethird of the companies and two-thirds of the profits. This highlights once again that the analysis faces quite severe data limitations, while also confirming the importance of using available data to understand more about the differences in tax behaviour of multinational 
groups headquartered in different economies (rather than relying, for example, on data for US-headquartered multinationals only).

\section{Conclusion}

The analysis here shows large variations between the location of real economic activity and the extent of profit declaration, or, equivalently, the difference between potential formulary apportionment mechanisms under a putative unitary taxation system in comparison to the current system of separate accounting.

The choice of apportionment factors is, unsurprisingly, of considerable importance. The different apportionment factors will result in very different redistributive outcomes. While total assets will change the relative allocation the least (with a surprise winner, Belgium), apportioning according to the number of employees will create the biggest redistribution.

Between the apportionment factors based on employment, apportionment according to payroll will harm the lowest-income countries in the sample (in Eastern Europe), while apportionment according to the number of employees will increase the size of their tax base.

By and large a shift to unitary taxation will - regardless of the apportionment factor - shift corporate tax base away from countries with 'favourable' tax regimes, for example, Luxembourg, the Netherlands and Ireland, which will see a smaller tax base under all scenarios.

In general the move towards unitary taxation results in a drop in corporate tax base of about 12 per cent due to international loss consolidation. It remains to be seen to what extent this reflects the global financial crisis falling into the period of analysis. Further work is also needed to investigate the extent to which this reflects a genuine reduction in the tax base, rather than being a feature of the sample period length or other components of the analysis.

The clearest result of this study, however, is that there is insufficient data to perform a full analysis of the revenue implications of a shift to unitary taxation - or, equivalently, of the scale of misalignment between corporate profits and the distribution of actual business activity. This is most glaringly true with respect to developing countries, which despite the global nature of the Orbis dataset are effectively excluded once the sample is required to include the standard set of possible apportionment factors. ${ }^{21}$ Further analysis with the current data may yield additional insights into patterns of profit distribution by income level, but such a sample cannot be relied upon to reveal a great deal about the pattern across developing countries of different regions, income levels and economic structure.

Nevertheless, the results at hand suggest that apportionment by number of employees in particular would have a very strong distributive effect - and these are likely, by and large, to have opposing tax base effects for the industrialised and lower-income countries. The possibility of redistribution of the tax base away from jurisdictions in which profit declaration is disproportionate to real economic activity, however, raises the possibility that unitary taxation could deliver benefits for most countries - while posing a significant threat to those that benefit most from the current system.

21 As such, these findings indicate a serious obstacle for the OECD's commitment to evaluate BEPS progress in reducing the misalignment of profits. 


\section{Appendix}

Table A1 Baseline results for tangible assets as apportionment factor

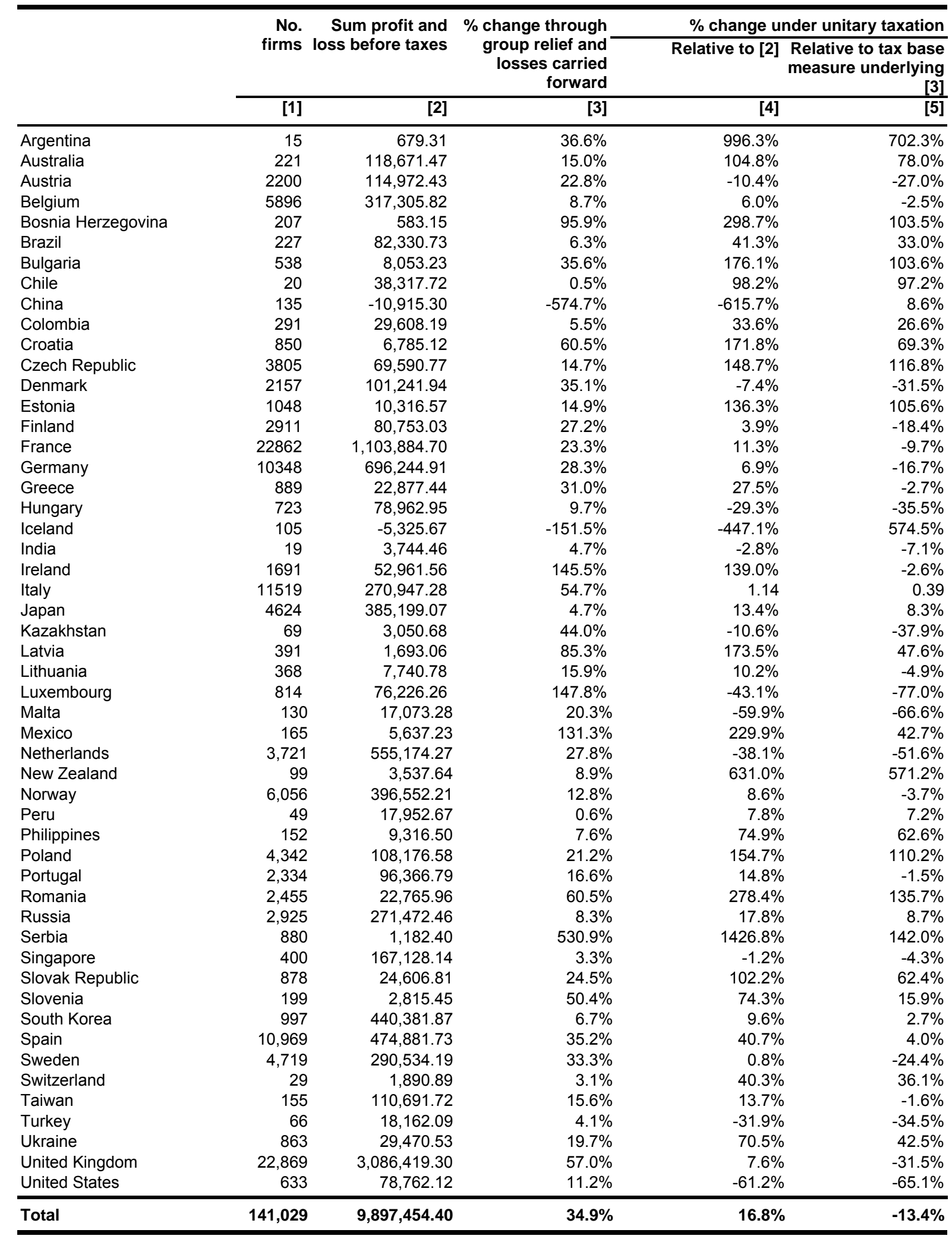

Notes: No. firms refers to the average (over the period 2003-2011) number of firms these results are based on. All countries with less than 10 firms on average in all apportionment factors are excluded. Sum profit and loss refers to the simple sum of profit and loss before taxes and is reported in million USD. 
Table A2 Baseline results for turnover as apportionment factor

\begin{tabular}{|c|c|c|c|c|c|}
\hline & \multirow{2}{*}{$\begin{array}{l}\text { No. } \\
\text { firms }\end{array}$} & \multirow{2}{*}{$\begin{array}{l}\text { Sum profit and } \\
\text { loss before taxes }\end{array}$} & \multirow{2}{*}{$\begin{array}{r}\% \text { change through } \\
\text { group relief and } \\
\text { losses carried } \\
\text { forward }\end{array}$} & \multicolumn{2}{|c|}{$\%$ change under unitary taxation } \\
\hline & & & & Relative to [2] & $\begin{array}{l}\text { Relative to tax base } \\
\text { measure underlying }\end{array}$ \\
\hline & [1] & [2] & [3] & [4] & {$[5]$} \\
\hline Argentina & 15 & 679.31 & $36.6 \%$ & $212.4 \%$ & $128.6 \%$ \\
\hline Australia & 236 & $244,682.32$ & $7.6 \%$ & $3.3 \%$ & $-4.0 \%$ \\
\hline Austria & 2,074 & $139,916.53$ & $23.4 \%$ & $13.0 \%$ & $-8.5 \%$ \\
\hline Belgium & 5,103 & $302,184.11$ & $33.5 \%$ & $25.1 \%$ & $-6.3 \%$ \\
\hline Bosnia Herzegovina & 217 & 964.58 & $73.2 \%$ & $114.7 \%$ & $24.0 \%$ \\
\hline Brazil & 246 & $84,875.08$ & $6.1 \%$ & $-9.1 \%$ & $-14.3 \%$ \\
\hline Bulgaria & 551 & $12,562.62$ & $23.7 \%$ & $48.7 \%$ & $20.2 \%$ \\
\hline Chile & 20 & $38,317.72$ & $0.5 \%$ & $21.3 \%$ & $20.7 \%$ \\
\hline China & 750 & $22,505.55$ & $305.3 \%$ & $331.6 \%$ & $6.5 \%$ \\
\hline Colombia & 293 & $30,030.67$ & $5.5 \%$ & $5.2 \%$ & $-0.2 \%$ \\
\hline Croatia & 870 & $13,146.01$ & $32.7 \%$ & $14.2 \%$ & $-14.0 \%$ \\
\hline Czech Republic & 3,838 & $95,971.15$ & $10.9 \%$ & $13.1 \%$ & $2.0 \%$ \\
\hline Denmark & 1,048 & $107,910.18$ & $20.0 \%$ & $12.6 \%$ & $-6.2 \%$ \\
\hline Estonia & 1,044 & $11,827.00$ & $13.1 \%$ & $8.3 \%$ & $-4.3 \%$ \\
\hline Finland & 2,989 & $106,727.82$ & $20.1 \%$ & $11.7 \%$ & $-7.0 \%$ \\
\hline France & 23,112 & $1388,937.60$ & $20.6 \%$ & $1.5 \%$ & $-15.9 \%$ \\
\hline Germany & 7,760 & $755,292.29$ & $29.5 \%$ & $28.8 \%$ & $-0.5 \%$ \\
\hline Greece & 896 & $1,052.47$ & $4,267.6 \%$ & $4,609.7 \%$ & $7.8 \%$ \\
\hline Hungary & 754 & $89,177.65$ & $9.8 \%$ & $14.7 \%$ & $4.4 \%$ \\
\hline Iceland & 79 & $-4,629.17$ & $-192.7 \%$ & $-163.3 \%$ & $-31.7 \%$ \\
\hline India & 337 & $23,168.04$ & $31.7 \%$ & $20.8 \%$ & $-8.3 \%$ \\
\hline Indonesia & 12 & 0.00 & $0.0 \%$ & 629.22 & 629.22 \\
\hline Ireland & 1,513 & $111,601.91$ & $36.1 \%$ & $10.2 \%$ & $-19.0 \%$ \\
\hline Italy & 11,678 & $387,362.78$ & $50.2 \%$ & $83.4 \%$ & $22.1 \%$ \\
\hline Japan & 4642 & $522,716.17$ & $4.9 \%$ & $7.4 \%$ & $2.4 \%$ \\
\hline Kazakhstan & 69 & $3,050.68$ & $44.0 \%$ & $-72.8 \%$ & $-81.1 \%$ \\
\hline Latvia & 469 & $1,570.68$ & $210.5 \%$ & $308.9 \%$ & $31.7 \%$ \\
\hline Lithuania & 396 & $8,092.88$ & $28.7 \%$ & $30.5 \%$ & $1.4 \%$ \\
\hline Luxembourg & 800 & $123,284.28$ & $93.2 \%$ & $-17.6 \%$ & $-57.3 \%$ \\
\hline Macedonia & 14 & 373.79 & $15.9 \%$ & $-0.7 \%$ & $-14.3 \%$ \\
\hline Malta & 135 & $18,844.27$ & $19.1 \%$ & $-60.4 \%$ & $-66.8 \%$ \\
\hline Mexico & 211 & $35,747.76$ & $21.7 \%$ & $-24.6 \%$ & $-38.0 \%$ \\
\hline Montenegro & 12 & 231.01 & $79.3 \%$ & $77.7 \%$ & $-0.9 \%$ \\
\hline Netherlands & 2,096 & $479,940.33$ & $15.0 \%$ & $-36.7 \%$ & $-45.0 \%$ \\
\hline New Zealand & 99 & $3,544.63$ & $8.9 \%$ & $91.1 \%$ & $75.5 \%$ \\
\hline Norway & 5,854 & $433,816.23$ & $11.1 \%$ & $-12.2 \%$ & $-21.0 \%$ \\
\hline Peru & 23 & $17,178.90$ & $0.3 \%$ & $-28.3 \%$ & $-28.5 \%$ \\
\hline Philippines & 164 & 10,797.01 & $7.0 \%$ & $16.1 \%$ & $8.5 \%$ \\
\hline Poland & 4,435 & $157,230.41$ & $14.8 \%$ & $27.9 \%$ & $11.4 \%$ \\
\hline Portugal & 2,242 & $103,834.66$ & $17.6 \%$ & $8.3 \%$ & $-8.0 \%$ \\
\hline Romania & 2,429 & $27,055.46$ & $54.0 \%$ & $95.8 \%$ & $27.1 \%$ \\
\hline Russia & 2,964 & $349,608.91$ & $6.8 \%$ & $-4.7 \%$ & $-10.7 \%$ \\
\hline Serbia & 896 & $2,685.57$ & $249.7 \%$ & $267.7 \%$ & $5.2 \%$ \\
\hline Singapore & 398 & $168,851.78$ & $3.3 \%$ & $33.6 \%$ & $29.4 \%$ \\
\hline Slovak Republic & 890 & $26,243.08$ & $24.0 \%$ & $51.0 \%$ & $21.8 \%$ \\
\hline Slovenia & 209 & $5,220.62$ & $45.6 \%$ & $44.2 \%$ & $-0.9 \%$ \\
\hline South Korea & 1,041 & $455,201.92$ & $8.5 \%$ & $-5.0 \%$ & $-12.5 \%$ \\
\hline Spain & 10,889 & $563,882.29$ & $31.3 \%$ & $20.7 \%$ & $-8.0 \%$ \\
\hline Sweden & 4,753 & $379,287.60$ & $27.2 \%$ & $-11.3 \%$ & $-30.3 \%$ \\
\hline Switzerland & 132 & $61,215.76$ & $10.9 \%$ & $2.4 \%$ & $-7.6 \%$ \\
\hline Taiwan & 155 & $110,691.72$ & $15.6 \%$ & $9.0 \%$ & $-5.6 \%$ \\
\hline Turkey & 86 & $37,827.20$ & $3.7 \%$ & $-11.0 \%$ & $-14.2 \%$ \\
\hline Ukraine & 858 & $30,098.81$ & $22.0 \%$ & $21.5 \%$ & $-0.4 \%$ \\
\hline United Kingdom & 19003 & 2331675.30 & $17.1 \%$ & $0.7 \%$ & $-14.0 \%$ \\
\hline United States & 667 & 220929.70 & $7.4 \%$ & $4.0 \%$ & $-3.2 \%$ \\
\hline Total & 132,468 & $10,654,994.00$ & $21.1 \%$ & $8.3 \%$ & $-10.6 \%$ \\
\hline
\end{tabular}

Notes: No. firms refers to the average (over the period 2003-2011) number of firms these results are based on. All countries with less than 10 firms on average in all apportionment factors are excluded. Sum profit and loss refers to the simple sum of profit and loss before taxes and is reported in million USD. In the case of Indonesia, the total amount allocated to the country is reported in the Table. 
Table A3 Baseline results for number of employees as apportionment factor

\begin{tabular}{|c|c|c|c|c|c|}
\hline & No. & Sum profit and & $\%$ change through & $\%$ change un & nder unitary taxation \\
\hline & firms & loss before taxes & $\begin{array}{r}\text { group relief and } \\
\text { losses carried } \\
\text { forward }\end{array}$ & Relative to [2] & $\begin{array}{l}\text { Relative to tax base } \\
\text { measure underlying }\end{array}$ \\
\hline & [1] & [2] & [3] & [4] & {$[5]$} \\
\hline Australia & 180 & $79,781.14$ & $17.6 \%$ & $30.5 \%$ & $11.0 \%$ \\
\hline Austria & 1,649 & $100,914.31$ & $24.3 \%$ & $-11.3 \%$ & $-28.6 \%$ \\
\hline Belgium & 5,221 & $299,774.80$ & $20.7 \%$ & $-24.5 \%$ & $-37.5 \%$ \\
\hline Bosnia Herzegovina & 213 & 951.35 & $73.6 \%$ & $447.6 \%$ & $215.4 \%$ \\
\hline Brazil & 106 & $24,244.44$ & $7.7 \%$ & $83.7 \%$ & $70.6 \%$ \\
\hline Bulgaria & 565 & $11,362.86$ & $25.9 \%$ & $168.4 \%$ & $113.2 \%$ \\
\hline China & 753 & $22,021.44$ & $310.2 \%$ & $688.0 \%$ & $92.1 \%$ \\
\hline Colombia & 39 & $4,900.26$ & $2.2 \%$ & $69.6 \%$ & $65.9 \%$ \\
\hline Croatia & 801 & $12,986.39$ & $31.6 \%$ & $77.9 \%$ & $35.2 \%$ \\
\hline Czech Republic & 3,232 & $89,309.41$ & $10.4 \%$ & $49.6 \%$ & $35.5 \%$ \\
\hline Denmark & 1,876 & $125,678.66$ & $23.9 \%$ & $0.8 \%$ & $-18.7 \%$ \\
\hline Estonia & 950 & $8,945.49$ & $13.5 \%$ & $93.4 \%$ & $70.4 \%$ \\
\hline Finland & 2,554 & $102,024.70$ & $19.5 \%$ & $7.2 \%$ & $-10.3 \%$ \\
\hline France & 22,015 & $1,222,765.40$ & $22.2 \%$ & $-15.7 \%$ & $-31.0 \%$ \\
\hline Germany & 6,134 & $636,147.43$ & $28.9 \%$ & $9.8 \%$ & $-14.8 \%$ \\
\hline Greece & 761 & -645.07 & $-6,755.2 \%$ & $-6,372.0 \%$ & $-5.8 \%$ \\
\hline Hungary & 425 & $26,194.30$ & $24.8 \%$ & $101.3 \%$ & $61.3 \%$ \\
\hline Iceland & 15 & $-1,722.93$ & $-235.7 \%$ & $-130.0 \%$ & $-77.9 \%$ \\
\hline India & 13 & $4,171.51$ & $10.8 \%$ & $80.6 \%$ & $63.0 \%$ \\
\hline Indonesia & 12 & 0.00 & $0.0 \%$ & $2,722,10$ & $2,722,10$ \\
\hline Ireland & 843 & $46,255.70$ & $55.0 \%$ & $-26.0 \%$ & $-52.3 \%$ \\
\hline Italy & 8,870 & $370,223.24$ & $43.5 \%$ & $62.8 \%$ & $13.4 \%$ \\
\hline Japan & 4,591 & $461,728.98$ & $4.4 \%$ & $0.7 \%$ & $-3.5 \%$ \\
\hline Kazakhstan & 34 & $1,564.28$ & $12.1 \%$ & $292.4 \%$ & $250.0 \%$ \\
\hline Latvia & 475 & $2,186.78$ & $121.5 \%$ & $529.0 \%$ & $184.0 \%$ \\
\hline Lithuania & 399 & $8,032.72$ & $28.7 \%$ & $107.1 \%$ & $60.9 \%$ \\
\hline Luxembourg & 244 & $87,114.93$ & $4.6 \%$ & $-65.5 \%$ & $-67.0 \%$ \\
\hline Macedonia & 12 & 268.46 & $10.5 \%$ & $377.2 \%$ & $331.8 \%$ \\
\hline Malta & 33 & $6,569.62$ & $3.3 \%$ & $-11.2 \%$ & $-14.1 \%$ \\
\hline Mexico & 105 & $23,409.30$ & $2.4 \%$ & $-1.1 \%$ & $-3.5 \%$ \\
\hline Montenegro & 11 & 207.56 & $87.1 \%$ & $248.6 \%$ & $86.3 \%$ \\
\hline Netherlands & 3,144 & $466,052.55$ & $15.9 \%$ & $-65.1 \%$ & $-69.9 \%$ \\
\hline Norway & 3,622 & $258,740.74$ & $9.2 \%$ & $-37.5 \%$ & $-42.8 \%$ \\
\hline Peru & 13 & $2,089.58$ & $3.4 \%$ & $33.3 \%$ & $28.9 \%$ \\
\hline Philippines & 19 & 2,795.86 & $3.8 \%$ & $33.2 \%$ & $28.4 \%$ \\
\hline Poland & 3,464 & $108,617.96$ & $11.6 \%$ & $136.0 \%$ & $111.6 \%$ \\
\hline Portugal & 1,689 & $81,559.07$ & $16.0 \%$ & $7.4 \%$ & $-7.4 \%$ \\
\hline Romania & 2,408 & $26,525.57$ & $53.9 \%$ & $372.9 \%$ & $207.3 \%$ \\
\hline Russia & 2,730 & $263,472.06$ & $8.2 \%$ & $24.1 \%$ & $14.6 \%$ \\
\hline Serbia & 893 & $2,568.20$ & $260.0 \%$ & $746.1 \%$ & $135.0 \%$ \\
\hline Singapore & 58 & $15,244.92$ & $6.6 \%$ & $-45.9 \%$ & $-49.3 \%$ \\
\hline Slovak Republic & 819 & $24,831.20$ & $24.7 \%$ & $112.6 \%$ & $70.5 \%$ \\
\hline Slovenia & 206 & $4,940.46$ & $47.8 \%$ & $42.1 \%$ & $-3.9 \%$ \\
\hline South Korea & 998 & $432,469.86$ & $8.9 \%$ & $1.8 \%$ & $-6.5 \%$ \\
\hline Spain & 9,755 & $471,178.72$ & $32.0 \%$ & $21.4 \%$ & $-8.0 \%$ \\
\hline Sweden & 6,668 & $346,056.55$ & $31.6 \%$ & $-20.5 \%$ & $-39.6 \%$ \\
\hline Switzerland & 85 & $30,531.40$ & $15.9 \%$ & $15.9 \%$ & $0.0 \%$ \\
\hline Taiwan & 145 & $106,733.12$ & $15.9 \%$ & $8.8 \%$ & $-6.1 \%$ \\
\hline Turkey & 29 & $19,134.29$ & $3.4 \%$ & $-12.7 \%$ & $-15.6 \%$ \\
\hline Ukraine & 854 & $29,868.91$ & $20.8 \%$ & $170.8 \%$ & $124.2 \%$ \\
\hline United Kingdom & 16,200 & $1,273,338.40$ & $29.6 \%$ & $27.1 \%$ & $-1.9 \%$ \\
\hline United States & 329 & $135,182.67$ & $4.8 \%$ & $-19.2 \%$ & $-22.9 \%$ \\
\hline Total & 117,259 & $7,879,299.60$ & $23.5 \%$ & $9.2 \%$ & $-11.6 \%$ \\
\hline
\end{tabular}

Notes: No. firms refers to the average (over the period 2003-2011) number of firms these results are based on. All countries with less than 10 firms on average in all apportionment factors are excluded. Sum profit and loss refers to the simple sum of profit and loss before taxes and is reported in million USD. 
Table A4 Baseline results for payroll as apportionment factor

\begin{tabular}{|c|c|c|c|c|c|}
\hline & \multirow{2}{*}{$\begin{array}{l}\text { No. } \\
\text { firms }\end{array}$} & \multirow{2}{*}{$\begin{array}{l}\text { Sum profit and } \\
\text { loss before taxes }\end{array}$} & \multirow{2}{*}{$\begin{array}{r}\text { \% change through } \\
\text { group relief and } \\
\text { losses carried } \\
\text { forward }\end{array}$} & \multicolumn{2}{|c|}{$\%$ change under unitary taxation } \\
\hline & & & & Relative to [2] & $\begin{array}{l}\text { Relative to tax base } \\
\text { measure underlying }\end{array}$ \\
\hline & [1] & [2] & {$[3]$} & {$[4]$} & [5] \\
\hline Austria & 1,550 & $105,202.21$ & $23.6 \%$ & $-0.2 \%$ & $-19.2 \%$ \\
\hline Belgium & 5,330 & $304,742.55$ & $8.3 \%$ & $-22.6 \%$ & $-28.6 \%$ \\
\hline Bosnia Herzegovina & 186 & 442.28 & $99.1 \%$ & $163.1 \%$ & $32.1 \%$ \\
\hline Bulgaria & 493 & $7,876.77$ & $34.7 \%$ & $-7.5 \%$ & $-31.3 \%$ \\
\hline Croatia & 794 & $6,736.11$ & $60.1 \%$ & $30.9 \%$ & $-18.2 \%$ \\
\hline Czech Republic & 3,296 & $68,575.50$ & $13.8 \%$ & $-15.1 \%$ & $-25.4 \%$ \\
\hline Denmark & 1,698 & $86,164.62$ & $24.7 \%$ & $-2.2 \%$ & $-21.5 \%$ \\
\hline Estonia & 744 & $7,518.64$ & $9.1 \%$ & $-12.6 \%$ & $-19.9 \%$ \\
\hline Finland & 2,672 & $64,141.99$ & $23.9 \%$ & $6.0 \%$ & $-14.4 \%$ \\
\hline France & 17,015 & $763,198.33$ & $20.3 \%$ & $16.4 \%$ & $-3.3 \%$ \\
\hline Germany & 6,678 & $631,807.26$ & $24.1 \%$ & $10.1 \%$ & $-11.3 \%$ \\
\hline Hungary & 696 & $77,996.68$ & $9.2 \%$ & $-10.7 \%$ & $-18.2 \%$ \\
\hline Iceland & 37 & 321.36 & $320.9 \%$ & $173.0 \%$ & $-35.2 \%$ \\
\hline India & 287 & $20,935.65$ & $33.1 \%$ & $-20.0 \%$ & $-39.9 \%$ \\
\hline Ireland & 798 & $33,629.19$ & $49.0 \%$ & $-20.2 \%$ & $-46.4 \%$ \\
\hline Italy & 9,972 & $268,381.46$ & $48.6 \%$ & $60.5 \%$ & $8.1 \%$ \\
\hline Japan & 1,547 & $143,429.24$ & $6.1 \%$ & $-4.4 \%$ & $-9.9 \%$ \\
\hline Latvia & 33 & -366.32 & $-163.9 \%$ & $-162.3 \%$ & $-2.4 \%$ \\
\hline Luxembourg & 466 & $72,042.12$ & $88.5 \%$ & $-62.0 \%$ & $-79.8 \%$ \\
\hline Malta & 12 & $1,563.73$ & $3.7 \%$ & -0.87 & -0.88 \\
\hline Netherlands & 1,092 & $103,691.86$ & $24.1 \%$ & $-47.2 \%$ & $-57.5 \%$ \\
\hline New Zealand & 83 & $2,883.43$ & $8.5 \%$ & $23.9 \%$ & $14.3 \%$ \\
\hline Norway & 3,986 & $209,153.57$ & $15.0 \%$ & $-4.2 \%$ & $-16.6 \%$ \\
\hline Poland & 3,378 & $75,266.17$ & $18.6 \%$ & $-17.7 \%$ & $-30.6 \%$ \\
\hline Portugal & 2,065 & $83,758.37$ & $15.9 \%$ & $1.8 \%$ & $-12.2 \%$ \\
\hline Romania & 2,125 & $23,731.93$ & $52.4 \%$ & $34.6 \%$ & $-11.6 \%$ \\
\hline Serbia & 839 & 1,217.36 & $511.8 \%$ & $562.5 \%$ & $8.3 \%$ \\
\hline Slovak Republic & 850 & $23,723.78$ & $25.3 \%$ & $13.6 \%$ & $-9.3 \%$ \\
\hline Slovenia & 194 & $2,810.07$ & $49.1 \%$ & $35.9 \%$ & $-8.8 \%$ \\
\hline South Korea & 847 & $91,476.30$ & $8.3 \%$ & $-18.6 \%$ & $-24.8 \%$ \\
\hline Spain & 10,017 & $448,961.80$ & $31.5 \%$ & $18.1 \%$ & $-10.2 \%$ \\
\hline Sweden & 3,714 & $109,706.61$ & $26.5 \%$ & $2.9 \%$ & $-18.6 \%$ \\
\hline Switzerland & 25 & $1,760.38$ & $3.3 \%$ & $2.9 \%$ & $-0.4 \%$ \\
\hline Taiwan & 149 & $109,360.05$ & $15.6 \%$ & $11.2 \%$ & $-3.8 \%$ \\
\hline Ukraine & 809 & $29,418.27$ & $19.6 \%$ & $-10.5 \%$ & $-25.2 \%$ \\
\hline United Kingdom & 15,318 & $1,176,679.20$ & $24.0 \%$ & $19.5 \%$ & $-3.7 \%$ \\
\hline Total & 99,795 & $5,157,938.50$ & $24.0 \%$ & $8.9 \%$ & $-12.2 \%$ \\
\hline
\end{tabular}

Notes: No. firms refers to the average (over the period 2003-2011) number of firms these results are based on. All countries with less than 10 firms on average in all apportionment factors are excluded. Sum profit and loss refers to the simple sum of profit and loss before taxes and is reported in million USD. 
Table A5 Baseline results for two-part apportionment factor according to Avi-Yonah et al (2009) - 1 per cent return in the first stage

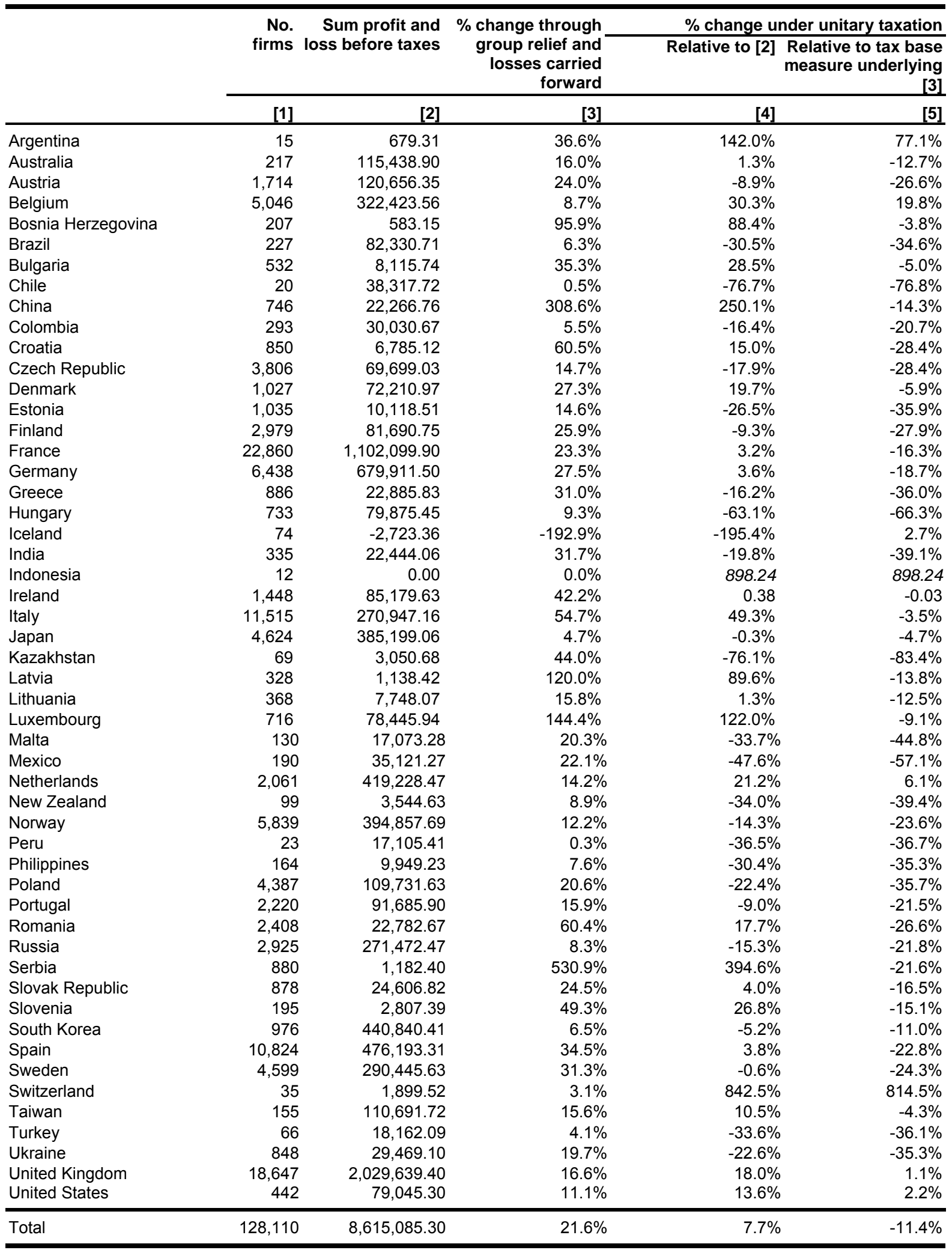

Notes: No. firms refers to the average (over the period 2003-2011) number of firms these results are based on. All countries with less than 10 firms on average in all apportionment factors are excluded. Sum profit and loss refers to the simple sum of profit and loss before taxes and is reported in million USD. In the case of Indonesia, the total amount allocated to the country is reported in the Table. 
Table A6 Baseline results for two-part apportionment factor according to Avi-Yonah et al (2009) - 5 per cent return in the first stage

\begin{tabular}{|c|c|c|c|c|c|}
\hline & \multirow{2}{*}{$\begin{array}{l}\text { No. } \\
\text { firms }\end{array}$} & \multirow{2}{*}{$\begin{array}{l}\text { Sum profit and } \\
\text { loss before taxes }\end{array}$} & \multirow{2}{*}{$\begin{array}{l}\% \text { change through } \\
\text { group relief and }- \\
\text { losses carried } \\
\text { forward }\end{array}$} & \multicolumn{2}{|c|}{$\%$ change under unitary taxation } \\
\hline & & & & Relative to [2] & $\begin{array}{l}\text { Relative to tax base } \\
\text { measure underlying }\end{array}$ \\
\hline & [1] & [2] & [3] & [4] & {$[5]$} \\
\hline Argentina & 15 & 679.31 & $36.6 \%$ & $134.0 \%$ & $71.2 \%$ \\
\hline Australia & 217 & $115,438.90$ & $16.0 \%$ & $7.4 \%$ & $-7.4 \%$ \\
\hline Austria & 1,714 & $120,656.35$ & $24.0 \%$ & $-0.8 \%$ & $-20.0 \%$ \\
\hline Belgium & 5,046 & $322,423.55$ & $8.7 \%$ & $24.6 \%$ & $14.6 \%$ \\
\hline Bosnia Herzegovina & 207 & 583.15 & $95.9 \%$ & $113.2 \%$ & $8.9 \%$ \\
\hline Brazil & 227 & $82,330.71$ & $6.3 \%$ & $-26.1 \%$ & $-30.4 \%$ \\
\hline Bulgaria & 532 & $8,115.74$ & $35.3 \%$ & $51.9 \%$ & $12.3 \%$ \\
\hline Chile & 20 & $38,317.72$ & $0.5 \%$ & $-76.2 \%$ & $-76.3 \%$ \\
\hline China & 746 & $22,266.77$ & $308.6 \%$ & $277.7 \%$ & $-7.6 \%$ \\
\hline Colombia & 293 & $30,030.67$ & $5.5 \%$ & $-10.8 \%$ & $-15.4 \%$ \\
\hline Croatia & 850 & $6,785.12$ & $60.5 \%$ & $25.2 \%$ & $-22.0 \%$ \\
\hline Czech Republic & 3,806 & $69,699.03$ & $14.7 \%$ & $-1.3 \%$ & $-13.9 \%$ \\
\hline Denmark & 1,027 & $72,210.97$ & $27.3 \%$ & $17.0 \%$ & $-8.1 \%$ \\
\hline Estonia & 1,035 & $10,118.51$ & $14.6 \%$ & $-18.0 \%$ & $-28.5 \%$ \\
\hline Finland & 2,979 & $81,690.75$ & $25.9 \%$ & $-1.3 \%$ & $-21.6 \%$ \\
\hline France & 22,860 & $1,102,099.90$ & $23.3 \%$ & $5.7 \%$ & $-14.2 \%$ \\
\hline Germany & 6,438 & $679,911.52$ & $27.5 \%$ & $11.3 \%$ & $-12.7 \%$ \\
\hline Greece & 886 & $22,885.83$ & $31.0 \%$ & $0.5 \%$ & $-23.3 \%$ \\
\hline Hungary & 733 & $79,875.46$ & $9.3 \%$ & $-43.6 \%$ & $-48.4 \%$ \\
\hline Iceland & 74 & $-2,723.36$ & $-192.9 \%$ & $-193.2 \%$ & $0.4 \%$ \\
\hline India & 335 & $22,444.07$ & $31.7 \%$ & $-8.6 \%$ & $-30.6 \%$ \\
\hline Indonesia & 12 & 0.00 & $0.0 \%$ & 430.18 & 430.18 \\
\hline Ireland & 1,448 & $85,179.62$ & $42.2 \%$ & 0.31 & -0.08 \\
\hline Italy & 11,515 & $270,947.15$ & $54.7 \%$ & $68.7 \%$ & $9.1 \%$ \\
\hline Japan & 4,624 & $385,199.07$ & $4.7 \%$ & $7.0 \%$ & $2.2 \%$ \\
\hline Kazakhstan & 69 & $3,050.68$ & $44.0 \%$ & $-80.0 \%$ & $-86.1 \%$ \\
\hline Latvia & 328 & $1,138.42$ & $120.0 \%$ & $152.7 \%$ & $14.9 \%$ \\
\hline Lithuania & 368 & $7,748.07$ & $15.8 \%$ & $5.7 \%$ & $-8.7 \%$ \\
\hline Luxembourg & 716 & $78,445.94$ & $144.4 \%$ & $91.8 \%$ & $-21.5 \%$ \\
\hline Malta & 130 & $17,073.28$ & $20.3 \%$ & $-44.3 \%$ & $-53.7 \%$ \\
\hline Mexico & 190 & $35,121.27$ & $22.1 \%$ & $-34.0 \%$ & $-45.9 \%$ \\
\hline Netherlands & 2,061 & $419,228.46$ & $14.2 \%$ & $5.8 \%$ & $-7.4 \%$ \\
\hline New Zealand & 99 & $3,544.63$ & $8.9 \%$ & $-11.6 \%$ & $-18.8 \%$ \\
\hline Norway & 5,839 & $394,857.68$ & $12.2 \%$ & $-13.9 \%$ & $-23.3 \%$ \\
\hline Peru & 23 & $17,105.41$ & $0.3 \%$ & $-35.3 \%$ & $-35.5 \%$ \\
\hline Philippines & 164 & $9,949.23$ & $7.6 \%$ & $-8.8 \%$ & $-15.3 \%$ \\
\hline Poland & 4,387 & $109,731.63$ & $20.6 \%$ & $-5.3 \%$ & $-21.4 \%$ \\
\hline Portugal & 2,220 & $91,685.90$ & $15.9 \%$ & $-5.5 \%$ & $-18.4 \%$ \\
\hline Romania & 2,408 & $22,782.67$ & $60.4 \%$ & $35.8 \%$ & $-15.3 \%$ \\
\hline Russia & 2,925 & $271,472.46$ & $8.3 \%$ & $-14.3 \%$ & $-20.8 \%$ \\
\hline Serbia & 880 & $1,182.40$ & $530.9 \%$ & $439.5 \%$ & $-14.5 \%$ \\
\hline Slovak Republic & 878 & $24,606.82$ & $24.5 \%$ & $19.2 \%$ & $-4.3 \%$ \\
\hline Slovenia & 195 & $2,807.39$ & $49.3 \%$ & $30.4 \%$ & $-12.7 \%$ \\
\hline South Korea & 976 & $440,840.41$ & $6.5 \%$ & $-7.1 \%$ & $-12.7 \%$ \\
\hline Spain & 10,824 & $476,193.33$ & $34.5 \%$ & $12.7 \%$ & $-16.2 \%$ \\
\hline Sweden & 4,599 & $290,445.61$ & $31.3 \%$ & $-3.1 \%$ & $-26.2 \%$ \\
\hline Switzerland & 35 & $1,899.52$ & $3.1 \%$ & $699.0 \%$ & $675.2 \%$ \\
\hline Taiwan & 155 & $110,691.72$ & $15.6 \%$ & $10.4 \%$ & $-4.5 \%$ \\
\hline Turkey & 66 & $18,162.09$ & $4.1 \%$ & $-24.7 \%$ & $-27.6 \%$ \\
\hline Ukraine & 848 & $29,469.10$ & $19.7 \%$ & $-14.0 \%$ & $-28.2 \%$ \\
\hline United Kingdom & 18,647 & $2,029,639.30$ & $16.6 \%$ & $13.6 \%$ & $-2.6 \%$ \\
\hline United States & 442 & $79,045.29$ & $11.1 \%$ & $12.8 \%$ & $1.6 \%$ \\
\hline Total & 128,110 & $8,615,085.20$ & $21.6 \%$ & $8.9 \%$ & $-10.5 \%$ \\
\hline
\end{tabular}

Notes: No. firms refers to the average (over the period 2003-2011) number of firms these results are based on. All countries with less than 10 firms on average in all apportionment factors are excluded. Sum profit and loss refers to the simple sum of profit and loss before taxes and is reported in million USD. In the case of Indonesia, the total amount allocated to the country is reported in the Table. 


\section{References}

Agúndez-García, A. (2006) 'The Delineation and Apportionment of an EU Consolidated Tax Base for Multi-jurisdictional Corporate Income Taxation: a Review of Issues and Options', European Commission Taxation Papers No. 9/06

Avi-Yonah, R., Clausing, K. and M. Durst (2009) 'Allocating Business Profits for Tax Purposes: A Proposal to Adopt a Formulary Profit Split', Florida Tax Review 9(5): 497553

Bureau van Dijk, Orbis, <http://www.bvdinfo.com/en-gb/our-products/companyinformation/international/orbis>

Clausing, K. (2014) Lessons for International Tax Reform from the US State Experience under Formulary Apportionment, ICTD Research Report 2, Brighton: International Centre for Tax and Development

_ and Lahav, Y. (2011) 'Corporate Tax Payments under Formulary Apportionment: Evidence from the Financial Reports of 50 Major U.S. Multinational Firms', Journal of International Accounting, Auditing and Taxation 20(2): 97-105

Cobham, A. and McNair, D. (2012) 'The role of rich countries in development: the case for reforms', in T. Hopper, M. Tsamenyi, S. Uddin and D. Wickramasinghe (eds), Handbook of Accounting and Development, Edward Elgar

Devereux, M. and Loretz, S. (2008) 'The Effects of E.U. Formula Apportionment on Corporate Tax Revenues', Fiscal Studies 29(1): 1-33

Eden, L. (2012) 'Transfer price manipulation', in P. Reuter (ed), Draining Development: Controlling Flows of Illicit Funds from Developing Countries, Washington DC: World Bank

European Commission (2011) Proposal for a Council Directive on a Common Consolidated Corporate Tax Base (CCCTB), Brussels COM(2011) 121/4, $<$ http://ec.europa.eu/taxation_customs/resources/documents/taxation/company_tax/co mmon_tax_base/com_2011_121_en.pdf>

Fuest, C., Hemmelgarn T. and Ramb, F. (2007) 'How Would the Introduction of an EU-wide Formula Apportionment Affect the Distribution and Size of the Corporate Tax Base? An Analysis Based on German Multinationals', International Tax and Public Finance 14: $605-626$

and Riedel, N. (2012) 'Tax evasion and tax avoidance: The role of international profit shifting', in P. Reuter (ed), Draining Development: Controlling Flows of Illicit Funds from Developing Countries, Washington DC: World Bank

_ Spengel, C., Finke, K., Heckemeyer, J. and Nusser, H. (2013) Profit Shifting and 'Aggressive' Tax Planning by Multinational Firms: Issues and Options for Reform, ZEW Discussion Paper No. 13-044

Grubert, H. and Mutti, J. (1991) 'Taxes, Tariffs and Transfer Pricing in Multinational Corporate Decision Making', Review of Economics and Statistics 73: 285-293 
Huizinga, H. and Laeven, L. (2008) 'International profit shifting within multinationals: A multicountry perspective', Journal of Public Economics 92: 1164-1182

International Monetary Fund (2014) Spillover in international corporate taxation, Washington: International Monetary Fund, available at

<http://www.imf.org/external/np/pp/eng/2014/050914.pdf>

Leite, C. (2012) 'The role of transfer pricing in illicit financial flows', in P. Reuter (ed), Draining Development: Controlling Flows of Illicit Funds from Developing Countries, Washington DC: World Bank

Loretz, S. and Mokkas, S. (2011) Evidence for profit shifting with tax sensitive capital stocks, Oxford University Centre for Business Taxation, Working Papers 11/16

Mintz, J. and Smart, M. (2004) 'Income Shifting, Investment, and Tax Competition: Theory and Evidence from Provincial Taxation in Canada', Journal of Public Economics 88: $1149-1168$

Murphy, R. (2012) 'Accounting for the missing billions', in P. Reuter (ed), Draining Development: Controlling Flows of Illicit Funds from Developing Countries, Washington DC: World Bank

_ (2008) The Missing Billions - the UK Tax Gap, Trades Union Congress, <http://www.tuc.org.uk/touchstone/Missingbillions/1missingbillions.pdf>

Nitsch, V. (2012) 'Trade mispricing and illicit flows', in P. Reuter (ed), Draining Development: Controlling Flows of Illicit Funds from Developing Countries, Washington DC: World Bank

OECD (2014) Report to G20 Development Working Group on the Impact of BEPS in Low Income Countries (Part I), OECD Publishing, <http://www.oecd.org/tax/tax-global/part1-of-report-to-g20-dwg-on-the-impact-of-beps-in-low-income-countries.pdf>

_ (2013) Action Plan on Base Erosion and Profit Shifting, OECD Publishing: <http://dx.doi.org/10.1787/9789264202719-en>

Picciotto, S. (2013) Is the International Tax System Fit for Purpose, Especially for Developing Countries?, ICTD Working Paper 13, Brighton: International Centre for Tax and Development, <http://www.ictd.ac/sites/default/files/ICTD\%20WP13_0.pdf>

Reuter, P. (ed) (2012) Draining Development: Controlling Flows of Illicit Funds from Developing Countries, Washington DC: World Bank

Shackelford, D. and Slemrod, J. (1998) 'The Revenue Consequences of Using Formula Apportionment to Calculate U.S. and Foreign-Source Income: A Firm-Level Analysis', International Tax and Public Finance 5: 41-59

Weichenrieder, A. (2009) 'Profit Shifting in the EU: Evidence from Germany', International Tax and Public Finance 16: 281-297 